\title{
PRISPEVEK K DATACIJI ROKOPISOV SKLADB JAKOBA FRANČIŠKA ZUPANA
}

1.0. Dosedanji poizkusi časovne umestitve ohranjenih in neohranjenih ter tudi le domnevanih skladateljskih dosežkov Jakoba Frančiška Zupana so brez izjeme ostajali na ravni spekulacij $\mathrm{z}$ bolj in manj afirmativno izrečenim hipotetičnim zaključkom ${ }^{1}$. Ob zadnje omenjenih dosežkih, katerih zgolj teoretična eksistenca ni nič manj spekulativna kot že provenienca, je to seveda razumljivo ${ }^{2}$, za neohranjeno ali vsaj še nepoznano Zupanovo uglasbitev opere Belin pa zaradi nejasnosti,

\footnotetext{
$1 \mathrm{Med}$ prvimi izstopa mnenje Dragotina Cvetka, “da je bila klasicistična orientacija na Slovenskem realna že pred zaključkom 18. stoletja, točneje pred nastopom njegovih 90-ib let. Vendar bržkone izključno le v reproduktienem smislu. 'Mala opera' Belin iz leta 1780 ali 1782 in ji je bil avtor Jakob Zupan, je bila komponirana, če sodimo po libretu, ki se je zgledoval pri Metastasiu - glasba se ni obranila -, $v$ duhu baročnega stila. Skladatelj Zupan se je pozneje sicer že približeval klasicizmu, vendar še ne ob vstopu v 80-leta." (D. Cvetko, Razvoine posebnosti glasbenega klasicizma na Slovenskem, str. 5. V: Zbornik referatov Mednarodnega simpozija, Ljubljana 1988, Evropski glasbeni klasicizem in njegov odmev na Slovenskem, SAZU, 1988.) Janez Höfler je v tem pogledu vsekakor manj določen. V nasprotju $\mathrm{s}$ Cvetkovim, ki si za izhodišče datiranja Zupanovih skladb izbere strukturo Devovega libreta, Höflerjev poizkus ne prestopi meja domnevnega, niti si ne dovoli sklepanja po analogiji. Opre se na znana skladateljeva biografska dejstva in iz njih razvije sklep: "Sodeč po letib njegovega [Zupanovega] delovanja v Kamniku labko domnevamo, da je začel skladati že vpetdesetib letih, ko ga je mogel pri tem še vzpodbujati njegov predstojnik. Valentin Götzl. V najsplošnejšem okviru pa bi njegova dela mogli postaviti nekako v razdobje od 1760 pa do 1790. V poznejših letib pa so njegove moči že pešale, tako da je mogel ustıarjati verjetno le še priložnostno." (J. Höfler, Tokovi glasbene kulture na Slovenskem, MK, Ljubljana 1970, str. 106.)

2 Gre za domnevo Ivana Klemenčiča o obstoju danes nepoznanih Zupanovih zgodnjeklasicističnih del iz začetka osemdesetih let, implicité izraženo v zapisu: "V začetek osemdesetib let sodi neobranjena glasba k operi Belin Jakoba Zupana in verjetno še diugo njegoto ustvarjanje, za katerega smemo realno domnevati, da je bilo zgodnjeklasicistično. Zupan je po prehodu, ki ga označuje staro in že novo, poglavitni predstaunik zgodnjega klasicizma v slovenski glasbi." (I. Klemenčič, Slogouni razuoj glasbenega baroka na Slovenskem, str. 37. V: Zbornik referatov z mednarodnega simpozija 13. in 14. oktobra $1994 \mathrm{v}$ Ljubljani, Glasbeni barok na Slovenskem in elropska glasba, Muzikološki inštitut ZRC SAZU, Ljubljana 1997.)
} 
ki pestijo branje temeljnega vira ${ }^{3}$ zanjo, navsezadnje tudí ${ }^{4}$ Kljub torej že tako dovolj nesrečni okoliščini, da je prav ta Pohlinova navedba edina, za katero vemo, ki na ravni historičnega vira posreduje letnico v zvezi s kako Zupanovo skladbo - kar bi ob enoznačnejši relaciji med obema (letnico in skladbo) seveda pomenilo eksakten datacijski datum, vendar ni tako.

Dosedanjim muzikološkim spekulacijam na temo kronološke razvrstitve Zupanovega ustvarjanja je potemtakem prostor krčilo prav dejstvo, da - razen biografskega okvira - ni zanega domala nič, kar bi kot (ne)posredni datum ali factum lajšalo datiranje tega ustvarjanja.

1.1. Ravno zato in $\mathrm{k}$ empirizmu nagnjenega dela muzikološke znanstvenosti bi v primerjavi $\mathrm{z}$ omenjeno teoretsko prakso veljalo k problematiki pristopiti tudi drugače. Ne toliko afirmativno, temveč informativno. Kajti bolj kot zapolnitev faktične praznine med referenčnima biografskima podatkoma ${ }^{6} s$ hipotetično kronologijo skladateljevega ustvarjanja $\mathrm{v}$ njej, kaže, da pespektivo ponujajo vprašanja, kot potencialno donosnejši odziv nanjo. Že zato, ker je vsaj za nekatera izmed njih odgovore moč doseči $z$ rezultati povsem empirično koncipiranih raziskav na ohranjenem delu Zupanovih skladateljskih dosežkov; kar pomeni pridobitev eksaktnih informacij o kronološki konfiguraciji le-teh, pa četudi le v obliki negativa ${ }^{7}$. Gre namreč za vprašanja, ki so v domači muzikološki literaturi že bila postavljena: "[...] ali je možno [Zupanova] klasicistična dela poleg osemdesetib let datirati $v$ sedemdeseta in celo $v$ šestdeseta leta, [...] ? Ali je možno, da bi že tedaj ustvarjal tako

\footnotetext{
3 Izvirno poročilo o Zupanovem skladateljskem prispevku k operi Belin prinaša t.i. licejski prepis Pohlinove Bibliothece Camiolae, nekdaj $\mathrm{v}$ lasti Žige Zoisa. Besedilo se glasi: Suppann (Iacob) Ludi, et Chori Magister Kamnecensis, egregius Compositor; et Musicus composuit melodias, et modas musicos: pro theatrali opera Carniolica: Bellin, ena opera, quam composuit, et 1780 . in 8 evulgavit P. Ioan. Damascenus, et sub Lit. I. invenies. Musices Ms. 1782. extabit Kamnecii. (NUK, Ms. 171, str. 105.) Po mnenju Ivana Prijatelja naj bi prepis izdelali Zupančič, Lužan in Kopitar na Dunaju konec leta 1808 in v začetku leta 1809 po tiskani predlogi iz leta 1803 (ki jo je po izvirnem avtorjevem rokopisu priredil Sartori), z namenom, da se kritično prečiščen in razširjen na novo izda v Ljubljani ob pomoči barona Zoisa. Pohlinov rokopis je po avtorjevi smrti prešel v last tedanjega kustosa dunajskega Terezijanišča Herbca, Pohlinovega prijatelja in kolege Sartorija. Od Herbčeve smrti dalje velja za izgubljenega. (Prim.: I. Prijatelj, Poblinova 'Bibliotheca Camiolae' v rokopisu licejske knjižnice, Izvestja Muzejskega društva za Kranjsko, Ljubljana 1905, str. 84 -91.)

4 Mnenje, po katerem naj bi Zupanova uglasbitev libreta Belin nastala v letih 1780 ali 1782, se opira na Dimitzev ponatis Pohlinove Bibliothece Camiolae (izšel v Ljubljani leta 1862 v okviru publikacij Historičnega društva za Kranjsko), ki poleg v nadaljevanju omenjene nejasnosti iz licejskega prepisa doda še svojo s premikom vejice za letnico 1780 (namesto: Bellin, ena opera, quam composuit, et 1780. in 8 evulgavit P. Ioan. Damascenus, Dimitzev ponatis prinaša besedilo: Bellin, ena opera, quam composuit et 1780, in 8. evulgavit [...]). Rudolf Flotzinger tako že leta 1982 opozori, da omenjeno besedilo ne more pomeniti nastanka glasbe, temveč natis besedila v Pisanicah leta 1780, in hkrati na nesmisel, ki sledi iz zapisa: Musices Ms. 1782 extabit Kamnecii. Flotzinger predlaga, naj se beseda extabit namesto kot prihodnjik glagola exsto (uporabljenega leta 1799, ko naj bi nastal Pohlinov izvirnik, za leto 1782) razume kot tiskarska oziroma prepisovalčeva napaka pri zapisu preteklika glagola extabesco (extabuit), kar bi pomenilo, da je bil tega leta rokopis Zupanove glasbe za Belina v Kamniku izgubljen oziroma uničen. (Prim.: R. Flotzinger, Zu den Anfängen des slowenischen Musiktheaters, str. 21-24. V: Zbornik referatov Simpozija 20. - 21. oktobra 1982 v Ljubljani, Slovenska opera v etropskem prostoru, Muzikološki inštitut ZRC SAZU, Ljubljana 1982.)

5 Razen dejstva, da je bil libreto za Belina natisnjen v Pisanicah leta 1780.

6 Gre za podatka, ki razkrivata časovni okvir Zupanovega bivanja na Slovenskem. To sta skladateljeva poroka z Josepho Götzl 3. avgusta 1757 (NŠAL, Kamnik, Poročne knjige, 1745-1769) in njegova smrt 11. aprila 1810. (NŠAL, Kamnik, Mrliške knjige, 1784-1812).

7 Ko Jan LaRue govori o splošnem pomenu in možnostih - v nadaljevanju prispevka predstavljene - papirološke metode, med drugim zapiše: "Evidence provided by watermarks is often general and sugestive ratber than specific or conclusive. Nevertheless such evidence may furnish decisive indications of date and provenance - often, admittedly, of negative kind." (New Grove Dictionary of Music, zv. XX, str. 228.) Vodni znaki so namreč $\mathrm{v}$ procesu datiranja lahko le terminus post quem, torej datum, pred katerim nastanek preučevanega rokopisa ni bil mogoč.
} 
zrela dela kot je Te Deum, deloma še razvidno poznobaročno pisana, [...], in že zgodnjeklasicistično? Ali bi labko tako značilno klasicistično oblikovane skladbe, kot so Litanije $v$ G-duru in še katere morda zgodnejše, nastale že v sedemdesetib letih, če že ne $v$ šestdesetih, ali pa jih je treba razvrstiti pozneje $v$ osemdeseta in še devetdeseta leta[...] ?"8

1.2. Med uveljavljenimi metodami ${ }^{9}$, ki muzikologom že dalj časa ${ }^{10}$ pomagajo do odgovorov na tovrstna vprašanja je tudi kombinacija papirološkega in grafološkega študija izvirnikov. Papirološki študij starejših glasbenih rokopisov ${ }^{11}$ obsega identifikacijo in primerjalno izvedeno datacijo papirja $s$ pomočjo vodnih znakov in posebnih lastnosti papirne mase ${ }^{12}$, grafološki študij analizo pisav(e) in notnega črtovja.

\section{Metodološka izhodišča:}

2.0.0. Poleg natančnosti in zajetnosti raziskav zahteva tak pristop tudi načelno zavedanje svojih meja, predvsem kar se neposrednega odnosa med njihovimi izsledki in datacijo skladb tiče ${ }^{13}$. Kajti kljub argumentom, s katerimi je pionir papirološkega raziskovanja na muzikološkem področju, Jan LaRue, izzval temeljni ugovor, ki opozarja na težko določljivo razliko med starostjo papirja in zapisa na njem ${ }^{14}$, njegova glavna posledica - degradacija tovrstnih datacij na raven negotove verjetnosti - še vedno ostaja. In zdi se, da je zgoraj omenjeni način uporabe pa-

8 Prim.: I. Klemenčič, Slogouni razıoj..., str. 38.

9 Poleg metod predstavljenih $\mathrm{v}$ nadaljevanju na primer še: metoda radiokarbonske analize črnila in papirja, ki pa je draga in nenatančna (prim.: Donald W. Krummel, Guide for dating early music: A Synopsis, FAM, XVIII/1971, št. 1-2, str. 55), ter metoda strukturne analize naslovnic (prim.: Liesbeth Weinhold, Musiktitel und Datierung, FAM, XIII/1966, št. 1, str. 136-140, in Wolfgang Matthäus, Die Elemente des Titelblattes im 18. Jabrhundert, FAM, XII/1965, št. 1, str. 23-26).

10 Papirološke metode so muzikologi - predvsem angleško govorečega območja - začeli uporabljati že sredi petdesetih let (npr. H.C.R Landon v študiji Haydnovih simfonij iz leta 1955), v večjem obsegu pa po objavi La Ruejevega članka Watermarks and Musicology (v AcM) leta 1961.

11 Ta študij je posebej učinkovit ravno za 18. stoletje, ko je zaradi skokovito naraščajočega povpraševanja in še vedno ročnega izdelovanja papirja (mehanizirana proizvodnja papirja se začne v zgodnjem 19. stoletju, pri nas v papirnici Vevče leta 1840) nastalo precej papirniških mlinov. Vsak mlin je izdeloval po nekaj vrst papirja, katere so lastniki zaznamovali vsako s svojim vodnim znakom. LaRue zameji "idealno obdobje" za tovrstne raziskave v leta od 1675 do 1825. (Prim.: J. LaRue, Watermarks and Musicology, AcM, XXIII/1961, str. 127.)

12 Glede na format, obliko, barvo, debelino in težo. Prim. še op. 19.

$13 \mathrm{Na}$ to opozarja tudi Alan Tyson, ko pravi: "The fatal error that is often made is the attempt simply to assign a date to a particular watermark, without considering who was using the paper:" (A. Tyson, Paper studies and Haydn: What needs to be done, str. 577 . V: Bericht über den internationalen Joseph Haydn Kongress, Dunaj, Hofburg, 5. - 12. september 1982.)

14 LaRue sicer priznava, da datacija papirja še ne pomeni datacije zapisa na njem. Vendar ob tem tudi utemeljeno zavrne ugovor, po katerem naj bi se papir v času njegove ročne izdelave pogosto kupilo v večjih količinah in shranilo za poznejšo rabo. Prvič, kot pravi LaRue, so taki primeri brez dvoma obstajali, vendar to ni bila običajna praksa. Drugič, papir je bil za kaj takega preprosto predrag. Celo založniki si tega niso mogli privoščiti, saj so papir kupovali na majhne zaloge. Tretjič, študij zapovrstnih del skladateljev pokaže, da se vodni znaki v neprimerno večjem številu primerov spreminjajo od skladbe do skladbe kot pa obratno. Kadar skladatelji niso uživali podpore bogatih mecenov, so iz finančnega razloga papir kupovali sproti, pač glede na aktualne potrebe. "[...] fresh paper every few days makes more sense than the vision of the music room crowded with great stacks of blank paper bought years earlier; from which be selected according to whim." (Prim.: J. LaRue, Watermarks..., str. 126-127.) In četrtič, raziskave rokopisov so pokazale (npr. Edwarda Heawooda), da so bili svežnji papirja z identičnimi vodnimi znaki navadno uporabljeni v relativno kratkem času. (Prim.: J. LaRue, geslo Watermarks, The New Grove Dictionary of Music, zv. XX, str. 128-129.) 
pirološke metode $\mathrm{v}$ kronološke namene, kot poti do odgovorov na vprašanja "ali je možno...?", obenem tudi edini, ki še vzdrži normativu konsistentnosti znanstvenega dokazovanja. (Vsekakor pa ob tem ne gre zanemariti njene praktične uporabnosti kot vira koristnih sugestij znotraj širšega raziskovalnega proce$\left.\mathrm{sa} .{ }^{15}\right)$

2.1.0. Že LaRue ter pozneje Alan Tyson in Howard Serwer ${ }^{16}$ so opozorili na možnost povečanja učinkovitosti papirološke metode $s$ pomočjo razlikovanja enakosti oblike (watermark-design) in identičnosti vodnih znakov ${ }^{17}$ (watermark). Identičnost primerjanih vodnih znakov je namreč lahko in edino le posledica odtisov $\mathrm{v}$ istem papirniškem kalupu (mould-mark), ki zaradi obrabe običajno v uporabi ni obstal dlje kot slabo leto. ${ }^{18}$ Ugotovitev identitete ${ }^{19}$ med že sicer enakimi znaki potemtakem pripomore $\mathrm{k}$ precej natančnejšemu določanju časovnega okvira pojavnosti nekega papirja, kar se kot posebej dobrodošlo izkaže pri tistih vodnih znakih, ki so v obtoku ostali tudi nekaj desetletij. ${ }^{20}$ (To v 18. stoletju sicer ni bilo pogosto, saj je trajanje enakega vodnega znaka redko preseglo dobo desetih let, vendar tudi ne povsem izključeno.) Nadaljnjo izostritev časovne podobe ročno izdelanih papirjev ponuja metoda t. i. progresivne deterioracije, ki izkorišča stopnjo deformacije odtisov posameznega znaka kot posledice vse večje obrabljenosti papirniškega kalupa ${ }^{21}$.

\footnotetext{
15 LaRue poleg dokazne vrednosti papirološke metode, ki je po njegovih besedah prej posredna kot neposredna, predstavi tudi povsem praktične razloge za uporabo le-te: "The obvious value of papyrological evidence lies in the general clues it furnishes concerning date and origin of musical material. These clues direct our searches for confirmation in other areas." (Prim.: J. LaRue, Watermarks..., str. 121.)
}

$16 \mathrm{~J}$. LaRue, Watermarks..., str. 123. Howard Serwer, Watermarks and rastral: Problems and possibilities, str. 573 (v: Bericht über den internationalen Joseph Haydn Kongress, Dunaj, Hofburg, 5-12. september 1982). Alan Tyson, Paper studies..., str. 578.

17 Vodni znak običajno sestavljata dva dela: znak (mark), ki označuje kakovost, format ali način obdelave nekega papirja, ter inicialke lastnika ali ime mlina oziroma ime kraja, kjer je ta obratoval (countermark). Največkrat se dela nahajata vsak na svoji, občasno pa tudi na isti polovici dvolistne pole papirja.

18 Oblika znaka je seveda kljub menjavanju posameznih kalupov (zaradi njihove obrabe) ostala enaka tudi desetletje in več. Vendar je zaradi ročne izdelave kalupov ob vsaki menjavi doživela rahle spremembe. Le dva v vseh podrobnostih popolnoma (!) enaka vodna znaka sta identična vodna znaka.

Glede na Piccardove, Gerardyjeve in njegove raziskave $s$ konca sedemdesetih let je Howard Serwer prišel do ugotovitve, da se je model ob vsakodnevni uporabi (10-12 ur) moral zamenjati približno vsakih osem mesecev. (Prim.: Howard Serwer, Watermarks and rastral..., str. 575.)

19 Gerardyjeva metoda identifikacije starejšega papirja poleg identitete vodnih znakov vključuje še identičnost papirne mase glede števila vzdolžnib (laid-lines) in razmaka naupičnih črt papirja (chain-lines) ter položaja znaka med njimi. (črte so posledica žičnate šablone, ki je med strjevanjem tekoče papirne gošče pomagala oblikovati list papirja.) Vendar pa tega v praksi pogosto ni mogoče ugotoviti; števila borizontal in položaja vodnega znaka zaradi fragmentacij papirja, razmaka vertikal pa zaradi posledic izdelovalnega postopka Nekajcentimetrski razmak vertikalnih žic šablone namreč pri vlivanju papirne gošče vanj ni ostal vedno enak. Odstopanje razmakov naupičnih črt papirja je nato povečevala še sklepna faza izdelovalnega postopka, ki je poleg sušenja vključevala še prešanje vlažnih papirnih pol, pri čemer so zaradi ne vedno iste sestave (gostote) papirne gošče in razlik v tlaku preše nastajali različno "raztegnjeni" listi papirja. Razdalje vertikalnih linij so tako lahko med seboj odstopale tudi za več milimetrov. Theodor Gerardy sam zaradi tovrstnih, kot pravi, standardnib deviacij temu določilu svoje metode ne namenja dokazne vrednosti, saj se z njim lahko ugotavlja le večja ali manjša verjetnost identičnosti. (Prim.: Theodor Gerardy, Datieren mit Hilfe von Wasserzeichen, Bückeburg 1964, str. 35-38.)

20 Vendar pa, obratno, neidentičnost dveh enakih vodnih znakov še ne pomeni, da papir z njima ne more biti enake starosti. Papirnišk mlini so namreč zaradi hitrejše proizvodnje papirja vedno v uporabi imeli vsaj dva enaka kalupa istočasno (t. i. tuin-moulds). (Prim.: Allan H. Stevenson, Watermarks are Twins, str. 57-91. V: Studies in Bibliography, Bibliographical Society of the University of Virginia, zv. IV/1951.)

21 J. La Rue, Watermarks..., str. 128-129. 
Opisane metodološke možnosti so teoretično vsekakor prepričljive (ob njih LaRue celo optimistično zapiše: "Working with large quantities of similar material and an initial framework of a few solid dates, by observing the development of minute alterations in the watermarks one may conceivably be able to construct a nearly complete cbronology." ${ }^{22}$ ), vendar praktično ne vedno izvedljive. Kajti, četudi izpustimo njihovo k (absolutni) dataciji usmerjeno strategijo ${ }^{23}$ ter jih uporabimo le za identifikacijo papirja in njegovo relativno kronologijo ${ }^{24}$, je obseg za to potrebnih raziskav v praksi lahko še vedno - nedoločno - večji od realno dosegljivega ${ }^{25}$. Poleg tega pa se metodi identifikacije in progresivne deterioracije vsaj do neke mere tudi izključujeta. Napredovanje deformacije enakib vodnih znakov namreč zmanjšuje možnost njihove identifikacije. (Primere iz ozke množice presečnosti obeh, ki seveda posredujejo najvišjo stopnjo gotovosti identitete, v praksi zasledimo sorazmerno redko.)

2.1.1. Večjo praktično vrednost gre metodi identifikacije priznati kot sredstvu negativnega dokazovanja in - zaradi njene skoraj filigranske natančnosti - kot pristopu ob ugotavljanju kronologije variantnib vodnih znakov. Ti se od enakih razlikujejo po večjih ali manjših oblikovnih spremembah motivično istih vodnih znakov istega papirniškega mlina. Za znak, ki v sebi kombinira po del lastnosti dveh variantnib vodnih znakov, namreč velja, da sodi v čas med njima ${ }^{26}$.

2.1.2 Status podobnosti vodnih znakov je za tovrstne papirološke študije redko uporabna kategorija ${ }^{27}$.

22 Ibid., str. 130.

23 Ta je statistične narave, saj je - ko ni neposrednih evidenc zanjo - "gotovost" tako pridobljene datacije linearno odvisna od števila referenčnih evidenc, pri čemer zgoraj omenjeni ugovor (glede razlike med starostjo papirja in zapisa na njem) seveda velja "na obe strani" referenčno in referirajočo se. Tudi zato datiranje s papirološko metodo ne zmore preseči ravni zgolj večje ali manjše (statistične) verjetnosti.

$24 \mathrm{~J}$. LaRue: "Even without papermaker's records, watermarks dates, or dated manuscripts, it is possible to construct a relative chronology for watermarks [...]". (J. LaRue Watermarks..., str. 128.)

25 Zavedati se namreč moramo, da je aktualno arhivsko gradivo $\mathrm{v}$ naših arhivih nemalokdaj precej nepopolno in ohranjeno le fragmentarno. Ponudba različnega papirja v obdobju, ko je gradivo nastajalo, pa je bila velika in predvsem izjemno pestra (prim. op. 11). Samo Kumarjev mlin v Ajdovščini je na primer leta 1771 izdeloval kar 32 vrst različnega papirja, na katerih so se vsakih nekaj let zvrstili novi, vsaj variantno spremenjeni vodni zanki. (V istem času so na Kranjskem delovali še trije večji papirniški mlini, vsak s svojo ponudbo papirja in svojimi vodnimi znaki.) Že izsleditev identičnega vodnega znaka tako ni niti samoumevna še manj pogosta, izsleditev tolikšne količine takih znakov, ki na podlagi različne stopnje deterioracije le-teh omogoči izdelavo relativne kronologije posameznega papirja, pa je v praksi prej stvar naključja kot posledica načrtovanega obsega raziskave.

26 LaRue poleg ugotavljanja relativne kronologije nekega vodnega znaka v ožjem smislu ( $\mathrm{z}$ metodo progresiune deterioracije) zagovarja tudi možnost izdelave relativnega kronološkega reda (oblikovnih) variant nekega daljše obdobje uporabljanega vodnega znaka, $s$ pomočjo identificiranja njegovih razvojnih teženj (developmental trends). (Prim.: J. LaRue, Watermarks..., str. 128.)

27 Jože Šorn se v svoji študiji Starejši mlini... (gl. op. 47) oprime tudi slogovne klasifikacije vodnih znakov, kar - z druge strani - vnovič implicira njihovo kronološko vrednost. Vendar je datiranje s pomočjo slogovnih značilnosti vodnih znakov lahko le zelo okvirno in zato praktično neuporabno. 
2.2.0. Če je namen papiroloških študij kronološka in geografska ${ }^{28}$ klasifikacija preučevanega papirja, pa grafološke ${ }^{29} \mathrm{v}$ prvi vrsti zanima identifikacija pisav $^{30} \mathrm{na}$ njem. Kronološka razčlenitev posameznih pisav s pomočjo notranje inkonsistence le-teh je sicer mogoča in koristna podpora širšemu dokazovanju ${ }^{31}$, vendar šele po opravljeni identifikaciji, stopnja nedvoumnosti zanjo potrebnih evidenc pa je pogosto neuporabno nizka; na eni strani zaradi ne vedno samo časovnega vzroka inkonsistentnosti pisave ${ }^{32}$, na drugi strani pa zaradi ne vselej povsem ločene (čiste) uporabe različnih tipov iste pisave. (Wolfgang Plath pisave 18. stoletja temeljno klasificira v tri, "rokokojskim piscem" samoumevne Schrifttypen: die Kalligraphie, die normale Gebrauchsschrift ter die flüchtige Skizzen-oder Konzeptschrift. ${ }^{33}$ )

2.2.1. Različni tipi pisave otežujejo njeno identifikacijo, saj v svoji čisti obliki ustvarijo vtis, kot bi nastali izpod rok različnih piscev ${ }^{34}$. Ingmar Bengtsson in Ruben Danielson sta zato na podlagi Schneikertove grafološke analitične metode $e^{35}$, ki primerjalno sooča posamezne izseke (units) izbranih pisav med seboj, razvila t. i. sistem grafemov. Ti zaradi svoje osredotočenosti na najmanjše enote neprekinjenih

\begin{abstract}
28 Poleg slogovnih večina vodnih znakov vsebuje še Širše geografske in celo krajevne značilnosti, ki pomagajo določiti kraj izvora papirja tudi brez identifikacije njegovega proizvajalca. LaRue zato vodne znake temeljno razvršča ravno po njihovih nacionalnih karakteristikah (prim.: J. La Rue, Watermarks..., str. 131-142). Georg Eineder podobno klasifikacijo zagovarja celo za samo papirno maso, katere kakovost in lastnost sta, kot pravi, neposredni odraz gospodarske ravni in socialne strukture okolja, v katerem je papirniški mlin obratoval. Preprosto zaradi razlik v kakovosti in lastnostih osnovne surovine za proizvodnjo papirja (starih cunj), ki se je spreminjala tudi glede na ekonomsko stanje in socialni profil prebivalstva med katerim se je ta nabirala. Zaradi merkantilističnih ukrepov tedanjih oblasti in stalnega primanjkovanja te surovine jo je bilo zvečine dovoljeno nabirati le v okviru deželnih meja. (Na Kranjskem so se po sprejetju Papierfabrikatus Ordnung leta 1754 tako zvrstili številni dekreti s prepovedjo izvoza starih cunj iz dežele.) Tako je na primer Koroška, ki je $\mathrm{v}$ tem obdobju preživljala hudo gospodarsko krizo, lahko $-\mathrm{v}$ nasprotju $\mathrm{z}$ beneškimi in dunajskimi mlini - proizvajala le najslabše vrste papirja. (Prim.: G. Eineder, The Paper-Mills..., str. 22 in 79. Gl. op. 45.)
\end{abstract}

29 Izšle so iz sodne grafologije. Pri tem je treba opozoriti, da te ne vključujejo, kot pravi H. Lennenberg, "the bighly debatable psychological analysis of handuriting characteristics". Zato se omenjeni avtor zavzame za Winternitzevo terminološko razločevanje med grafologijo in grafografijo: "Graphographic analysis comprises a definition of handwriting units and a description of their characteristics with a view to arriving at a reliable identification." (Prim.: Hans Lenneberg, Handuriting Identification and Common Sense, FAM, XXVII/1980, št. 1, str. 30.) Grafološke (= grafografske) analize je muzikologija začela uporabljati sredi petdesetih let tega stoletja v zvezi $\mathrm{z}$ identifikacijo Bachovih in Mozartovih avtografov. (Prim.: Wolfgang Plath: Beiträge zur Mozart-Autographie I: Die Handschrift Leopold Mozarts. V: Mozart-Jahrbuch 1960/1, str. 83.)

30 Seveda mora aplikacija grafološke metode na področje muzikologije ločiti med notnim (Notenschrift) in črkouno-besednim (Wort-oz. Buchstabenschrift) delom neke pisave. Pri zadnjem pa še - kar je posebej pomembno za Zupanov primer - med njenim nemskim (gotica) in latinskim (latinica) delom. (Prim.: W. Plath: Beiträge zur..., str. 84.)

31 Uspešen poizkus takega dokazovanja je bila na primer Hilmarjeva kronološka razčlenitev Schubertovih rokopisov $s$ pomočjo notranjega razvoja skladateljeve pisave. (Prim.: Ernst Hilmar, Datierungsprobleme im Werk Schuberts, str. 45-60. V: Bericht, Schubert-Kongress Wien 1978, Akademische Druck, Gradec 1979.) Wolfgang Plath razlikuje med dvema namenoma grafološke analize: prvi je identifikacija pisca oziroma njegove pisave, drugi njena kronološka razčlenitev. (Prim.: W. Plath, Beiträge zur..., str. 82.)

$32 \mathrm{H}$. Lenneberg navaja šest nekronoloških vzrokov variabilnosti neke pisave: emocionalni stres, hitrost pisanja, namembnost rokopisa, splošno zdravje pisca, težave z vidom in svetlobo, artritis (prim.: H. Lenneberg, Handwriting..., str. 31); Alan Tyson pa še pomanjkanje prostora za pisanje $\mathrm{v}$ notni vrsti ali na listu papirja v celoti (prim.: A.Tyson, Notes on Five of Beethoven's Copyists, JAMS, XXIII/1970, str. 443).

33 "Jeder Schreiber; der kalligraphisch begabt und geschult ist, verfügt über mebrere Schrifttypen, die einander auf den ersten Blick nicht unbedingt äbnlich zu seben brauchen." Pri tem je treba razlikovati med čisto (Reinschriff) in nečisto uporabo navedenih tipov (gl. tudi op. 32). (Prim.: W. Plath, Beiträge zur..., str. 86.)

34 "In Fällen, wo diese Schrifttypen einigermassen rein zutage treten, wird der eilige Betrachter dazu neigen, verschiedene Schreiberbände anzunebment." (Prim.: Ibid.)

35 Razvita je bila za potrebe sodne grafologije. (Hans Schneikert, Die technische Nachueisung von Schriftfälschungen unter besondererBerücksichtigung der Photographie, 4.ed., Jena 1943.) 
potez pisave (a unit of unbroken movement of penmanship) ${ }^{36}$ omogočajo učinkovito izslediti notranjo enovitost njenih navzven tudi povsem različnih tipov. ${ }^{37}$

Analitični del identificiranja pisav pozornost usmerja predvsem k njihovim posebnim (primarnim) značilnostim ${ }^{38}$. Tovrstnemu pristopu poleg t. i. Sonderfällen ${ }^{39}$ glavne nevšečnosti povzročata še nedoslednost $v$ razvoju posamezne pisave ter sočasno nastopajoča variabilnost oblike njenih znakov (units; v notnem zapisu na primer ključev, predznakov, oznak ritmičnih načinov, not, pavz, ipd.).

2.2.2. Nič manj pomembno kot analitično razčlenjevanje je v procesu identifikacije pisav tudi intuitivno opazovanje celostne podobe le-teh. Teoretiki grafološke analize opozarjajo, da preučevanje pisav ne temelji na kvantitativnih metodah znanstvene analize, temveč na izkušnjah pridobljenih $\mathrm{v}$ praksi (npr. Ingmar Bengtsson in Ruben Danielson) ${ }^{40}$ ter na univerzalni sposobnosti likovnih spoznav, kvalitativno analitičnih in intuitivnih. ${ }^{41}$ Wolfgang Plath zato na podlagi predhodnega razločevanja med "die einzelnen Notenformen" in "die Gesamterscheinung des Scbriftbildes" izpelje temeljno delitev meril grafološke identifikacije na: Speziellein Allgemeine Kriterien der Unterscheidung der Handschrift. Slednji se razen na psihološki profil pisočega v prvi vrsti osredotočajo na - tudi slogovno določljive kaligrafske norme in manire obdobja, $v$ katerem je preučevani zapis nastal. Predvsem zato, ker te skozi svoje odtenke odsevajo razlike v stopnji, času in kraju pridobljene izobrazbe pisočih ${ }^{42}$.

2.2.3. Analiza notnega črtovja, navadno sproti zarisovanega s petkoničnim peresnikom (rastral), sestoji iz meritev razdalje med posameznimi črtami (single span) in skupnega obsega črtovja (total span). Čeprav v manjšemu obsegu, lahko tudi ta

36 Prim.: Barry S. Brook in Marvin E. Paymer, Pergolesis Hand: eine kalligraphische Studie, Mf, XXXV/1982, š. 1, str. 20.)

37 W. Plath tako razlikuje med "die innere Einheit der Handschriff" in "die äusserliche Verschiedenheif". (Prim.: W. Plath, Beiträge zur:.., str. 86.)

38 Emanuel Winternitz loči dvoje značilnosti neke pisave: primame (neobičajne, posebne) in sekundame (ki reproducirajo nadosebne "pisarske" manire nekega časa in prostora) (v: H. Lenneberg, Handwriting..., str. 30). Wolfgang Plath v tem pogledu razlikuje med: die speziellen in allgemeinen Charakteristika (prim.: W. Plath, Beiträge..., str. 87-92), Hans Schneikert pa med: erst- in zueitrangigen Charakteristika. Bary S. Brook primarne značilnosti (t. j. typischen Kennzeichen) neke pisave zaradi njihove odločilnosti pri postopku grafološke identifikacije opredeli kot "die Hauptcharakteristika" (prim.: B. Brook in M. Paymer, Pergolesis..., str. 15).

39 Prim.: W. Plath, Beiträge zur:.., str. 90.

$40 \mathrm{~V}:$ H. Lenneberg, Handuritig..., str. 31.

41 Hans Lenneberg: "The experience referred to here is the universal ability to recognize a familiar handwriting not lonlyl on the basis of individual letters or even graphemes, but by its general appearance which probably depends on such factors as the size of the script, maigins, slope, slant and space between lines, words and letters, elements our eyes take in at glance and which, experience teaches us, are quite reliable." (Ibid., str. 32.)

42 Wolfgang Plath pri razločevanju pisav Leopolda in Wolfganga A. Mozarta izhaja iz klasifikacije splošnih značilnosti pisave, kot jo je v letih Leopoldovega šolanja gojil salzburški jezuitski kolegij in ki je bila vse do njegove razpustitve čvrsto zavezana poznobaročnim maniram kaligrafije. Takšna klasifikacija je seveda uporabna tudi ob identifikaciji Zupanove pisave. (Prim.: W. Plath, Beiträge zur:.., str. 88.) 
pripomore pri identificikaciji in kronološki razvrstitvi preučevanih glasbenih zapisov. ${ }^{43}$

\section{Rezultati raziskave:}

3.0.0. Papirološka in grafološka raziskava skladateljske zapuščine Jakoba Frančiška Zupana je zajela vse znane in $v$ Sloveniji hranjene rokopise njegovih skladb. Primerjalni vzorec referenčnih virov so na eni strani sestavljali notni arhivi ljubljanske stolnice, novomeškega kapitlja in frančiškanskega samostana ter tri ohranjene muzikalije iz komendske knjižnice P. P. Glavarja, na drugi strani pa ohranjene listine, dokumenti in knjige $\mathrm{v}$ knjižnicah frančiškanskega samostana $\mathrm{v}$ Kamniku in P. P. Glavarja v Komendi, arhivsko gradivo mesta Kamnik v MAL ter župnijskih arhivov Kamnika, Komende in Kranjske Gore, hranjeno v NŠAL in župnišču v Komendi. Obseg in vsebino vzorca sta torej določali merili nahajališča ohranjenih rokopisov Zupanovih skladb in kraja skladateljevega prebivanja na slovenskih tleh $^{44}$. Rezultati raziskave so bili sproti primerjani $z$ vsebino naslednje referenčne literature: $\mathrm{z}$ Einederjevim katalogom The ancient Paper-Mills of the former AustroHungarian Empire and their Watermarks ${ }^{45}$, Zumanovo Ceske filigrany XVIII. stolet $i^{46}$ in s Šornovo študijo Starejši mlini za papir na Slovenskem ${ }^{47}$.

3.1.0. Omenjeni rokopisni opus Zupanovih skladb obsega sto dvaindvajset listov ročno izdelanega papirja, od tega dvanajst nerazpolovljenih in trinajst razpolovljenih ter enajst posamičnih polovic dvolistnih pol. Preostali listi so fragmentacije večinoma komplementarnega dela posamičnih polovic papirnih pol. Sto trinajst listov vsebuje odtise vodnih znakov: deset celih (znak in inicialke na nerazdvojeni dvolistni poli), triintrideset polovičnih (ali znak ali inicialke), pri preostalih gre za bolj in manj med seboj komplementarne fragmente. Od tega je neenakih dvajset vodnih znakov (Sl. 1-15) ${ }^{48}$, med njimi sedem variantnib.

3.2.0. Na vsega dvaindvajset (posamezno signiranih) rokopisih Zupanovih skladb ${ }^{49}$ je svojo pisno sled zapustilo kar šest različnih rok. Pet pisav je po tipu kaligrafskib

\footnotetext{
43 Prim.: A. Tyson, Paper Studies and Haydn: What needs to be done, str. 578. V: Bericht über den internationalen Joseph Haydn Kongress, Dunaj, Hofburg, 5. - 12. september 1982.

44 O Zupanovem bivanju v Kranjski Gori leta 1808 priča ohranjeni prepis njegovega pisma hčerki (iz leta 1813), ki naj bi ga od tod poslal 16. oktobra 1808. (NŠAL, Kamnik, Razni spisi, f. 16.)

45 Georg Eineder, The ancient Paper-Mills of the former Austro-Hungarian Empire and their Watermarks, Monumenta chartae-papyraceae bistoriam illustrantia, zv. VIII, The paper publications society, Hilversum 1960.

46 František Zuman, Česke filigrany XVIII. stoleti, Razpravy česke akademie ved a umeni, I/78, Praga 1936.

47 Jože Šorn, Starejši mlini za papir na Slovenskem, Zč, 1954/VIII, št. 1-4, str. 87-117.

48 Ilustracije vodnih znakov v slikovni prilogi so predstavljene v merilu $1: 2,1$.
}

49 Rokopis Zupanove Regine coeli $\mathrm{z}$ alternativnim besedilom Salve Regina iz novomeškega kapitlja se je po njegovi najdbi leta 1967 izgubil. Dosegliju je le v obliki fotografij $v$ lasti Janeza Höflerja.

Prof. J. Höflerju se za poklon omenjenih fotografij iskreno zahvaljujem. 
(A, B, C, D, E, Tabele I - IV), dve pisavi sta normalno uporabnega tipa, med njima je ena le tipska varianta prve izmed petih kaligrafskih pisav ${ }^{50}$.

3.3.0. S prvo izmed kaligrafskih pisav, pisavo A, so napisani vsi Zupanovi vokalnoinstrumentalni dueti in arije $\mathrm{e}^{51}$, dvaindvajset $\mathrm{v}$ celoti ali le fragmentarno ohranjenih skladb drugih ali neidentificiranih avtorjev, prav tako iz novomeške knjižnice frančiškanskega samostana ${ }^{52}$, ter dva violinska fragmenta stavka Et incarnatus est neidentificirane maše, hranjene v komendski knjižnici P. P. Glavarja ${ }^{53}$. Besedni del te pisave srečamo še na nekaterih cerkvenih listinah in v matrikah kamniške župnije zadnje četrtine 18. stoletja; med prvimi najbolj razločno na Sumarischer Extract $\tilde{f}^{4}$ finančnega poročila kamniške župnijske cerkve za leto 1783 , v finančnem poročilu ${ }^{55}$ za leto 1788 in na listini Currende ${ }^{56} \mathrm{z}$ dne 6. septembra 1792. Samostojne vpise $\mathrm{v}$ krstne in mrliške knjige $s$ to pisavo zasledimo $\mathrm{v}$ obdobju od začetka leta 1776 do prvih let 19. stol., dopise domačih imen in popravke priimkov k starejšim matrikam, vpisanim z drugo pisavo in črnilom, pa tudi za leta pred 1776. Ob enem takšnih (vpisu rojstva nekega Gregoriusa Laurentya Vaupetezha z dne 10. aprila $1763)^{57}$ je nad imenom dodanega dopisa Vulgo Pierz pripisano še: boc cognomen adituus Suppan ad...?].

Vodni znaki novomeških rokopisov Zupanovih arij in duetov so v slikovni prilogi numerirani od 1 do 9 .

3.3.1. Prvi (Sl. 1) je fragment zgornje polovice kače na križu žužemberškega papirničarja Antona Nikla ${ }^{58}$. Nahaja se na enem od dveh izvodov Organo separata latinskega dueta O gloriosa Virginum (NmF, Ms. mus. 51b). Jože Šorn v svoji študiji "kranjskih" mlinov za papir datira začetek pojavnosti tega znaka že v leto 1734 , vendar študij zgoraj navedenega referenčnega vzorca tega ni potrdil. Od vstopa $v$ 40. pa vse do začetka 50. let se namreč v pregledanem gradivu pojavlja izključno

\footnotetext{
$50 \mathrm{Na}$ prvem od dveh v nadaljevanju obravnavanih izvodov separata Oigano latinskega dueta O gloriosa Virginum (NmF, Ms. mus. $51 \mathrm{~b})$.

51 Skupno osemnajst skladb, hranjenih v knjižnici novomeškega frančiškanskega samostana: Ms. mus. 48, 48a/b/c/d, 49a, 51a/b/c, $52 \mathrm{a} / \mathrm{b} / \mathrm{d} / \mathrm{e} / \mathrm{f} / \mathrm{g}, 53 \mathrm{a} / \mathrm{b} / \mathrm{c}$.

$52 \mathrm{NmF}$, Ms. mus. 50c, 52c, 114a, 115a, 116a, 116c, 141 (sedem fragmentov različnih skladb), 145, 279, 440, 441, 454, 484, 485, 507, 508.

53 Separata Violino Primo in Violino Secondo, priložena v tiskano zbirko Octo Missae bavarskega skladatelja p. Lamberta Krausa iz leta 1762.

54 NŠAL, Kamnik, Razne knjige, f. 1.

55 Ibid.

56 NŠAL, Kamnik, Razni spisi, f. 16.

57 NŠAL, Kamnik, Krstne knjige, 1760-1784.

$58 \mathrm{~J}$. Šorn, Starejši mlini..., str. 114. Več o zgodovini tega, $\mathrm{v}$ prvi polovici 18. stoletja najpomembnejšega papirniškega mlina pri nas, $\mathrm{v}$ istem Šornovem članku na str. 92-93.
} 
le starješa varianta ${ }^{59}$ obravnavanega znaka, ki jo ta nato v celoti nasledi do začetka 60. let 18. stoletja ${ }^{60}$. To potrjuje Šornovo domnevo, da je Antonov sin Dizma Nikel moral ta vodni znak uporabljati še nekaj let po očetovi smrti leta 1756, s starimi inicialkami $\mathrm{AN}^{61}$. Zasledimo ga na številnih muzikalijah in listinah iz 50. in začetka 60. let 18. stoletja: enakega na že omenjenem fragmentu violinskih separatov mašnega stavka Et incarnatus est in zadnji strani vezave violinske šole Leopolda Mozarta iz leta 1756, ki se nahajata v knjižnici P. P. Glavarja v Komendi; nadalje na vezavi znamenitega Glavarjevega Status animarum ${ }^{62}$ za leta 1754-1760, ki je bil sodeč po obsegu neuporabljenih strani v knjigo vezan pred njegovo uporabo; na vezavah tiskanih zbirk Kobrichovih maš in ofertorijev ${ }^{63}$ iz leta 1756 ter fragmentu Basso ${ }^{64}$ separata neznane arije (napisanem $s$ pisavo D) v novomeškem frančiškanskem samostanu; na vezavi in vseh notranjih listih kamniškega urbarskega in davčnega registra ${ }^{65}$ iz leta 1756 , na nekem potrdilu ${ }^{66}$, izdanem v Kamniku Vallentinu Schagarju 12. junija 1762 , in specifikaciji ${ }^{67}$ računa, priloženi $\mathrm{k}$ finančnemu poročilu kamniške župnije za leto 1768 ; ter na dveh pogodbah ${ }^{68}$, sklenjenih v Komendi 4. marca 1757 in 30. maja 1758.

Čeprav je obravnavani vodni znak ohranjen fragmentarno, na polovici desnega lista dvolistne pole, pa je zaradi velikosti in značilno oblikovane glave (kače), oblike ust in mesta očesa, kota ovojev telesa kače okoli križa, razpona prečnice križa

59 V slikovni prilogi Šornovega članka prikazana pod št. 10. V gradivu frančiškanskega samostana v Novem mestu jo je zaslediti: na notranjih listih vezave (v nad. vezava) rokopisne knjige liturgičnih skladb Ms. mus. 91; na dodanih listih - str. 135-139 - h knjigi liturgičnih skladb Ms. mus. 247 (obe knjigi je napisala ista roka kot podobno knjigo Maš: Pro Choro Neostadiensi 1751, Ms. mus. 246); na vezavi nekaterih tiskanih zbirk liturgičnih skladb (Hirschbergerjeve Philomela Cisterciensis iz leta 1743 (323); Kaltnerjeve XXVI. Hymni Vespertini iz 1749 (324); Röslerjeve IV. Litaniis lauretanis iz leta 1749 in Königspergerjeve IV. Stabat Mater iz 1748 (337), ki vsebujejo tudi rokopisne notne vstavke $s$ prej omenjeno pisavo). $\mathrm{V}$ knjižnici frančiškanskega samostana $\mathrm{v}$ Kamniku: na vezavi tiskanega pevskega učbenika Fundament, Esst Unterricht des Coräll Gesangs. V arhivskem gradivu kamniške župnije: na cerkvenih računih iz 1743 in 1744 (NŠAL, Kamnik, Razne knjige, f. 2). V arhivskem gradivu komendske župnije: v Krstni knjigi 1751-1779 in na cerkvenih računih iz let 1743 , 1745 in 1746 (NŠAL, Komenda, Listine iz 18. stol., f. 16/3). V arhivskem gradivu kranjskogorske župnije: na raznih pogodbah za leta 1745 , 1746 in 1748 (NŠAL, Kranjska Gora, Razne listine 18. stol. in zač. 19. stol., f. 2).

60 Ko ga nasledijo precej drugačne variante z inicialkama DN (Dizma Nikel). Te variante zapovrstno srečamo na številnih rokopisnih muzikalijah in listinah iz 60., 70. in prve polovice 80. let 18. stoletja (leta 1786 je Niklov mlin najverjetneje prenehal delovati (prim.: J. Šorn, Starejši mlini..., str. 92-93)), tudi na nekaterih muzikalijah iz novomeškega frančiškanskega samostana: Ms. mus. 102, 113a, 115b, 128, $145,152,282,291,460$, in kapitlja: Ms. mus. 57.

61 Prim.: J. Šorn, Starejši mlini..., str. 115.

62 Status animarum, 1754-1760, Podvuzhenie, ali Sprashevanie Tiga potrebniga kershanshega Navuka sa te maibne otrokbe, 1754. Nahaja se v župnišču v Komendi.

$63 \mathrm{NmF}, 327$ in 328.

$64 \mathrm{NmF}$, Ms. mus. 490.

65 NŠAL, Kamnik, Urbarski in davčni register 1756.

66 NŠAL, Kamnik, Obrestni kapitalij 1762, f. 13/a.

67 Specification k Stain Stadt Pfarr-kürchen Rattung za leto 1768 je izdelal in podpisal Zupanov predhodnik in tast Valentini Francisci Götzl / als geordneten kürchen Bropsten U:L:F: der Statt:Pfarr:kürchen zu Stain. Finančno poročilo za leto 1768 je kaligrafskega tipa in napisano na papirju $\mathrm{z}$ drugačnim vodnim znakom (lev $\mathrm{z}$ inicialkami IGT) kot k njemu priložena Specification, ki je napisana $v$ pisavi konceptnega tipa in na manjšem, od večjega odrezanem listu Niklovega papirja. Najverjetneje gre za primer uporabe nekaj let starejšega papirja. (NŠAL, Kamnik, Razne knjige, f. 2.)

68 NŠAL, Komenda, Listine iz 18. stol., f. 16/3. 
in njenega dotika $z$ glavo, pa tudi razmaka navpičnih črt papirne mase vseeno mogoče natančno ugotoviti njegovo identiteto $\mathrm{z}$ nekaterimi od enakib vodnih znakov v omenjenem vzorcu raziskave. Povsem identičen vodni znak zasledimo na fragmentu separata Canto Solo arije Te Matrem amamus ${ }^{69}$, napisanem $\mathrm{z}$ isto pisavo (A). Razen $\mathrm{v}$ razmaku navpičnih črt papirne mase so $\mathrm{z}$ njima identični tudi vodni znaki pevskih separatov rokopisa Responsoria pro quatuor Matutinis in bebdomada Sancta $^{70}$, ki na naslovnici razkriva ime svojega nekdanjega lastnika $\mathrm{z}$ napisom: Ex Rebus Simonis Gatterer, in letnico 1759.

3.3.2.a. Vodni znak drugega izvoda separata Organo je prav tako fragmentaren. Sestoji iz zgornjega dela leve polovice znaka $\boldsymbol{S} \boldsymbol{v}$. Vid $\boldsymbol{s}$ palmo (Sl. 2/a). Isti vodni znak in inicialke ICVS pod njim prinašajo še separati ${ }^{71}$ latinskega dueta Maria, gustum sentio (NmF, Ms. mus. 51c), napisani na enaki papirni masi in $\mathrm{z}$ isto barvo črnila $^{72}$. Gre za koroški papir šentviškega mlina na reki Glini ${ }^{73}$. Slednjemu identičen vodni znak vsebujejo trije fragmenti ${ }^{74}$ arij $\mathbf{v}$ novomeškem frančiškanskem samostanu, napisani na enaki papirni masi ter $\mathrm{z}$ isto pisavo in črnilom, precej spremenjeno varianto $z$ inicialkami I.C.V.S.F. pa listina Ertragnus ${ }^{75}$, datirana $s 23$. marcem $1778 \mathrm{v}$ Komendi. Podobnejšo varianto, $\mathrm{z}$ inicialkami ICVS na drugem delu dvolistne pole, je najti na vezavi komendskega Status animarum ${ }^{76}$ za leta 1761-1766; le-ta $z$ ločitvijo inicialk od znaka kot tudi $z$ obliko njegove spodnje strani (kotla) jasno kaže prehodne poteze med tu obravnavanim znakom in naslednjo varianto (Sl. 2/b).

$69 \mathrm{NmF}$, Ms. mus. $141 \mathrm{~b}$.

70 Hranjen $v$ ljubljanski stolnici.

71 Naslovnica/Alto desno polovico in Canto levo polovico vodnega znaka. Organo spodnji del leve, Violino Primo spodnji del desne in Violino Secondo zgornji del desne polovice vodnega znaka. Pri slednjem manjka ravno tisti del vodnega znaka (zgornji del leve polovice), ki ga vsebuje obravnavani izvod separata Organo.

$72 \mathrm{Ta}$ je kot pri številnih kaligrafskib primerih te pisave značilne svetlorjave barve. Barva črnila prej obravnavanega izvoda istega separata je precej temnejša (črna). Pisava na njem je primer uporabnega tipa pisave A (gl. op. 50 in Tabelo III, A/a).

73 Nastanek tega mlina sega v začetek 16. stoletja. Proti koncu 17. stoletja je prešel v last Hansa Zengerja, ki je s svojim papirjem oskrbel tudi Valvasorja pri izdelavi njegove Vojoodine Kranjske. (Prim.: Eineder, The ancient Paper-Mills..., str. 81.) Na dokumentih prve polovice 18. stoletja je zaslediti precej primerov papirja z (variantmim) vodnim znakom $S v$. Vida in inicialkami WZ, ki po vsej verjetnosti označujejo potomca starega lastnika: npr. v rokopisni knjigi Večne maše 1717-1736 (NŠAL, Kamnik, Večne maše 1717-1736) in na cerkvenih računih kamniške župnije iz let 1744 in 1746 (NŠAL, Kamnik, Razne knjige, F. 2); ter na cerkvenih računih komendske župnije iz let med 1723 in 1727 (NŠAL, Komenda, Listine iz 18. stol., f. 16/3). Inicialki WZ (pogosto tudi z znakom poštnega roga) v obtoku ostaneta do leta 1764, ko mlin dokončno prevzame novi lastnik Johann Caspar von Schwerenfeld, katerega inicialke (ICVS ali ICS) poleg prejšnjih vzporedno zasledimo že proti koncu 50 . let 18. stoletja. V obtoku ostanejo vse do prve polovice 90 . let, vendar od sredine 70. let 18. stoletja ne več ob znaku z motivom Sv. Vida, temveč z značilno šesterokrako zuezdo in veliko krono.

74 Separati Alto Viola obligata (NmF, Ms. mus. 484) ter Violino Primo in Violino Secondo (NmF, Ms. mus. 507 ).

75 ŠAL/Ž, Komenda, f. 123.

76 Examen Doctrinae Christi [1761-1766], Status animarum. Kot prejšnji je tudi ta napisan s pisavo P. P. Glavarja. Nahaja se v župnišču v Komendi. 
3.3.2.b. Vodni znak Sv. Vida (brez palme) (Sl. 2/b) se nahaja na separatih" Regina coeli v G-duru (NmF, Ms. mus. 48c) ter na naslovnici Scheiblove Misse ex A major $^{78} \mathrm{v}$ novomeškem frančiškanskem samostanu, napisani $\mathrm{s}$ pisavo $\mathrm{D}$.

3.3.2.c. Fragment njegove variante (Sl. 2/c), z inicialkami ICS, zasledimo na dveh separatih $^{79}$ ohranjenega dueta Salve Regina (NmF, Ms. mus. 48b). Sodeč po papirni masi in položaju spodnjega dela znaka imata enak vodni znak tudi dva $\mathrm{z}$ isto pisavo napisana violinska fragmenta ${ }^{80}$ arije Non confundar iz novomeškega frančiškanskega samostana. Einederjev katalog datira pojav tega znaka z letnico $1764^{81}$, vendar bi glede na kronološko jasne oblikovne značilnosti njegovih variant in negotovost datacij omenjenega kataloga ${ }^{82}$ to letnico kazalo pomakniti vsaj za nekaj let nazaj.

3.3.3. Obsežnejša skupina ${ }^{83}$ dveh variant vodnih znakov so večji in manjši samorogi radeškega papirničarja Andreja Müllerja ${ }^{84}$. Kot je ugotovil Jože Šorn, bi natančnejša obravnava Müllerjevega papirja morala $\mathrm{k}$ raziskavi $\mathrm{v}$ prvi vrsti pritegniti arhivski material nekdanje Spodnje Štajerske, ki je radeškemu papirničarju pomenila večji del njegovega tržišča ${ }^{85}$. To je brez dvoma tudi glavni razlog, da je tu predstavljeni raziskavi med vsem pregledanim gradivom uspelo izslediti le pet neposredno in tri posredno ${ }^{86}$ referenčne primere Müllerjevih vodnih znakov.

\footnotetext{
77 Naslovnica/Violino Primo cel znak, Violino Secondo zgornjo polovico znaka, Canto Solo spodnjo polovico in Organo zgornjo polovico inicialk.

$78 \mathrm{NmF}$, Ms. mus. 123.

79 Canto Primo spodnja polovica znaka, Violino Secondo zgornja polovica inicialk.

80 Violino Primo in Violino Secondo, NmF, Ms. mus. 141c.

81 Pod kataloško št. 822.
}

$82 \mathrm{~V}$ uvodu kataloga avtor pojasni princip datiranja vanj vključenih vodnih znakov ter obseg izbirnega in primerjalnega vzorca virov. Datiranje je upoštevalo najstarejši v raziskavi najdeni vir $z$ ustreznim vodnim znakom, vzorec raziskave pa sta sestavljala le dva izbrana dunajska arhiva (Archiv der Stadt Wien in Hofkammer Archiv). To je povzročilo nekaj let premlade datacije večine že tako nepopolno zbranih vodnih znakov papirja iz nekdanjih avstrijskih provinc (tudi Kranjske, Koroške in Štajerske). Primer tega je tudi Einederjeva datacija starejše variante šentviškega vodnega znaka Sv.Vida (z inicialkama WZ) z letnico 1763 (pod kataloško št. 825). Tak vodni znak je namreč zaslediti že na listinah iz srede 50. let 18. stoletja: npr. na neki poročni pogodbi, sklenjeni v Kamniku 19. julija 1755 (MAL, KAM 105/a. 1. 39).

83 Zaradi nazornosti drobnih razlik med enakimi, a iz različnih (neidentičnih) kalupov izhajajočimi vodnimi znaki, so v slikovni prilogi predstavljene vse opažene "variante" njihovih odtisov.

84 Papirni mlin v Radečah pri Zidanem Mostu je začel delovati ok. leta 1750 . V začetku njegova proizvodnja ni presegla 112 rizmov papirja na leto (medtem ko je na primer Kumarjev mlin v Ajdovščini že kmalu po nastanku leta 1769 uspel proizvesti od 6000 do 7000 rizmov). Naraščajoče povpraševanje in naglo propadanje Niklovega mlina v Žužemberku (Dizma Nikel je bil, verjetno tudi zaradi svoje hromosti, $v$ primerjavi $\mathrm{z}$ očetom precej manj podjeten in za delo v mlinu neizučen) je v 60 . letih Müllerjevemu mlinu omogočilo precejšnjo konjunkturo. Deloval je do konca 70. let 18. stoletja. (Prim: J. Šom, Starejši mlini..., str. 94-95 in 115-116.)

85 "Ker Müllerjevega papirja na Kranjskem ni mnogo (usmerjenost $v$ Spodnje Štajersko!), moremo trditi, da smo našli le manjši del njegovib znakov." (J. Šorn, Starejši mlini..., str. 116.)

86 Gre za dva primera vodnega znaka leva z zemeljsko kroglo: na naslovnici Ivančičevih Lytaniae Lauretanae, z napisom Ex $M: M: C P M 780$ [1780] (NmF, Ms. mus. 54b) in pismu c.kr. dvornega agenta Ferdinanda Müllerja mestnim očetom mesta Kamnik, iz 14 . maja 1782 (MAL KAM 117, št. 1/c/3). Tretji je primer Müllerjevih inicialk AM na Cardinovem pismu kamniškim mestnim očetom, odposlanem iz Ljubljane 2. junija 1781 (MAL, KAM 117, št. $1 / \mathrm{c} / 2$ ). 
3.3.3.a/1/2/3. S prvim (Sl. 3/a-1) izmed treh enakih, a na različnih kalupih odtisnjenih malib samorogov, je označen papir separatov ${ }^{87}$ Himnusa Egregie Doctor Paule (NmF, Ms. mus. 49a), z drugim (Sl. 3/a-2) naslovnica oziroma drugi altovski separat nemškega dueta Mutter der Lieblichkeit (NmF, Ms. mus. 52f), s tretjim (Sl. 3/a-3) pa separata Violino Primo in Violino Secondo istega dueta, kar pomeni, da njuna odtisa najverjetneje izhajata iz t. i. kalupa-dvojčka ${ }^{88}$.

Šornu je v njegovi raziskavi kranjskih mlinov za papir, sodeč po formulaciji aktualnega dela besedila $v$ članku, uspelo izslediti dokument $s$ takšnim vodnim znakom, datiranim že $\mathrm{z}$ letom $1766^{89}$. Tu predstavljena raziskava je bila $\mathrm{v}$ tem pogledu kljub krajevni neustreznosti njenega vzorca uspešna kar v dveh primerih enakib vodnih zankov. Prvega izmed njiju zasledimo na vezavi in vseh notranjih listih kamniškega Repertorium Missarum $^{90}$, z uvodnikom iz 24. aprila 1770, drugega na separatih Ivančičevih Lytaniae Lauretanae, katerih spodnji desni kot naslovnice ( $\mathrm{z}$ drugačnim vodnim znakom ${ }^{11}$ ) prinaša tudi $\mathrm{z}$ isto pisavo in črnilom zapisani zaznamek: $E x$ M:M: CPM 780[1780].

Enak vodni znak je najti še na prilepljenih listih vezave rokopisne zbirke klavirskih skladb $^{92}$ iz novomeškega frančiškanskega samostana. Informacijo o dataciji te vezave, čeprav le posredno, posredujeta njena prosta lista $s$ Kumarjevim vodnim znakom velikonočnega jagnjeta iz leta $1771^{93}$, ki se je, kot kaže, v obtoku obdržal le do izteka 70. let 18. stoletja ${ }^{94}$.

3.3.3.b/1/2/3. Večjo varianto Müllerjevega samoroga bi, kot kaže, veljalo postaviti v isti čas kot manjšo. K temu navaja separat Alto Primo že navedenega dueta Mutter der Lieblichkeit, ki v nasprotju z drugimi separati ( $z$ manjšim samorogom) sam prinaša prvo (Sl. 3/b-1) od treh različic velikega samoroga. Nekoliko drugačen odtis enakega vodnega znaka (Sl. 3/b-2) se nahaja na naslovnici ${ }^{95}$ nemškega dueta Nichts ist treus auf dieser Erden (NmF, Ms. mus. 52g), spet drugačen (Sl. 3/b-3) pa

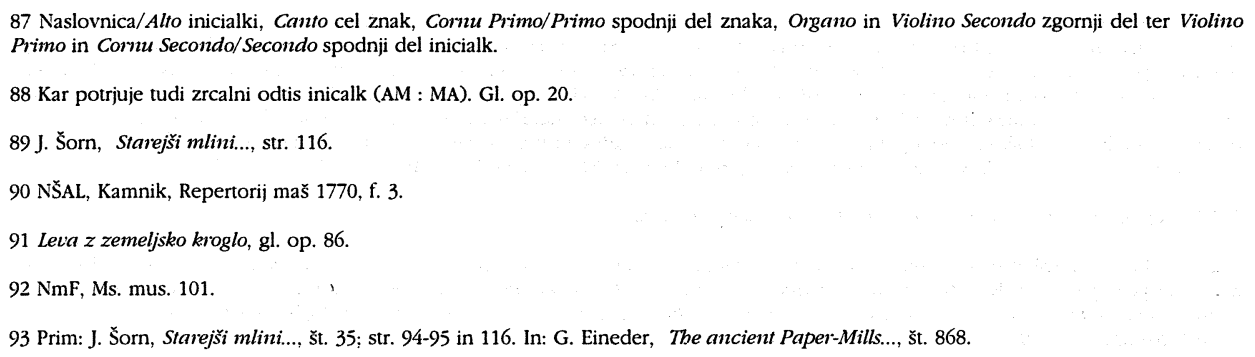

94 Po letu 1780 vsebuje pregledano gradivo le nekoliko bolj stilizirano varianto tega znaka, prav tako z inicilkama TC: npr. na Obračunski knjigi kamniškega kıznarskega ceba iz leta 1780 (MAL, KAM 105/a. 1. 44), ali na komendskih Status animarum za leta 17811785 in 1786-1790 (v župnišču v Komendi). Čeprav tega znaka literatura izrecno ne navaja, pa smemo s precejšnjo gotovostjo domnevati, da gre za mlajšo varianto Kumarjevega velikonočnega jagnjeta iz 70 . let: prvič, zaradi vsebine inicialk, drugič, zaradi njihove podobne stilizacije, kot jo izkazujejo nekatere druge Kumarjeve inicialke (prim.: J. Šorn, št. 37), tretijč, zaradi izjemno velike navzočnosti papirja $s$ takšnim vodnim znakom pri nas, in četrtič, zaradi njegove aktualnosti ravno do nastopa novega lastnika Kumarjevega mlina $v$ začetku 90. let (gl. op. 103).

95 Njemu pripadajoči inicialki AM vsebuje separat Canto Primo istega dueta. 
na preostalih separatih ${ }^{96}$ prav tako že omenjenega latinskega dueta $O$ gloriosa Virginum.

Med vsem pregledanim gradivom je bilo takšne vodne znake zaslediti le na vezavi nekaterih starejših, na novo prevezanih knjig iz komendske knjižnice P. P. Glavarja.

3.3.4. Na eni takšnih srečamo tudi podoben vodni znak $^{97}$, kot ga imajo separati ${ }^{98}$ novomeškega rokopisa Zupanove uglasbitve sekvence Stabat mater (NmF, Ms. mus. 48a), ki prinašajo Müllerjevo" kopijo znaka škofa s palico, sicer značilnega za Thalbergov papirniški mlin na Zgornjem Štajerskem ${ }^{100}$. In čeprav Müllerjev znak v nasprotju z znaki zgornještajerskega mlina, ki reproducirajo omenjeni motiv ${ }^{101}$, ne vključuje ravno glavnega škofovskega atributa, temveč papeški trojni križ na palici, pa preostali del podobnosti z znakom iz komendske knjižnice vendarle razločno kaže željo po posnemanju ${ }^{102}$ tržno najuspešnejšega papirja na tedanjem Štajerskem.

Referenčnega primera k Müllerjevemu znaku papeža s palico (Sl. 4) v pregledanem gradivu ni bilo zaslediti.

3.3.5a/b. Zadnjo skupino tu predstavljenih variantnih vodnih znakov sestavljata levčka ajdovskega papirničarja Tomaža Kumarja ${ }^{103}$. Prvi (Sl. 5/a) se nahaja na sep-

96 Naslovnica/Alto cel znak, Canto celi inicialki, Violino Primo spodnji del in Violino Secondo zgornji del znaka.

97 Thalbergov škof s palico (prim. op. 100, 168 in 193). Nahaja se na vezavi tretje knjige iz serije Fiuchtbarer Himmels Thau (Frankfurt, 1745). G. Eineder v svojem katalogu, st. 747, postavi začetek pojavnosti tega znaka v leto 1773. Vendar zapis na sprednjem prilepljenem listu vezave: Laurenij Stotelsek Coop. ad St. Paule 766, Julij[1766], temu vsekakor ne pritrije. Najverjetneje gre za še eno netočno (premlado) datacijo v Einederjevem katalogu. (Gl. tudi op. 82.)

98 Naslovnica/Alto cel znak, Canto celi inicialki, Organo concerto spodnji del znaka, Violino Primo zgornji del znaka, Violino Secondo zgornji del inicialk.

99 Pri tem je še posebej zanimivo, da se ok. leta $1750 \mathrm{v}$ graškem papirniškem mlinu Graz-Leuzendorf, edinem resnejšem konkurentu Thalbergovega mlina (gl. op. 100), omenja papirniški mojster $\mathrm{z}$ imenom Andre Müller. (Prim.: G. Eineder, The ancient Paper-Mills..., str. 76.)

100 Zgornještajerski papirniški mlin severno od Rohrbacha, imenovan Thalberg, je ustanovil graški jezuitski Kolegij ok. leta 1750. Po razpustu jezuitskega reda (1773) je prešel v državno last. Po Einederjevem mnenju je lastnikom mlina kljub precej slabi kvaliteti njihovega papirja uspelo $v$ kratkem času osvojiti večji del štajerskega tržišča predvsem zaradi protekcije pri graških deželnih in gubernijskih oblasteh, ki so za svojo administrativno dejavnost potrebovale velike količine papirja. Poleg tega je bilo mesto Gradec v tistem času, predvsem s severne strani transportno zelo težko pristopno, kar je uvoz sicer neprimerno boljšega dunajskega papirja nekonkurenčno podražilo. Posledica je bil skoraj monopolni položaj tega mlina na Štajerskem v prvih desetletjih druge polovice 18. stoletja. Večji del njihovih vodnih znakov je vseboval motiv škofa s palico. (Prim.: Eineder, The ancient Paper-Mills..., str. 71-72 in 77-78.)

$101 \mathrm{~V}$ pregledanem gradivu je bilo zaslediti kar 10 variant tega znaka.

102 To je bila tedaj sploh pogosta praksa manjših papirničarjev. Znane so na primer številne češke imitacije tedaj izjemno cenjenega nizozemskega papirja HONIG. "Lesser makers found better markets if they imitated more famous names in their watermarks (Honig of Amsterdam was a frequent victim)" (J. LaRue, geslo Watermarks..., str. 231. In: isti, Watermarks.., str. 139). Prim. tudi: G. Eineder, The ancient Paper-Mills..., str. 90.

103 Papirniški mlin Tomaža Kumarja v Ajdovščini je začel obratovati januarja 1768. Že leta 1771 (po Šornu 1769) je njegov izredno podjetni lastnik poslal na Dunaj (v Hofkammer) v pregled 32 (leta 1775 pa kar 39) vzorcev različnega papirja. Ta je od vsega tedaj na Slovenskem proizvedenega papirja daleč prednjačil po svoji kakovosti in konkurenčni ceni. Svojim beneškim konkurentom pa Kumar ni sledil le $s$ kvaliteto, prevzel je tudi njihovo maniro označevanja papirja $\mathrm{z}$ inicialkami (TC) v spodnjem kotu ene od polovic dvolistne pole (od znaka oddvojene inicialke se pri nemškem in avstrijskem papirju po pravilu nahajajo na sredini lista). V 70. letih 18. stoletja se je Kumar razvil $v$ enega najuglednejšib in najmočnejšib papinničavjev v austrijskib dednib deželab. Svoje izdelke je prodajal na Goriškem, Kranjskem, v Trstu (od tam tudi v tujino) in na Reki. Proti koncu 80. let je proizvodnja zaradi obnemoglosti lastnika počasi začela upadati. Po njegovi smrti je aprila leta 1793 mlin prevzel novi lastnik Karl Boromej Fajenz. Ta je ob inicialkah CBF oz. KBF uporabljal tudi povsem drugačne vodne znake. (Prim.: J. Šorn, Starejši mlini..., str. 94-95 in 116.) 
aratih $^{104}$ latinskega dueta Sacris solemniis (NmF, Ms. mus. 53c) ter na sicer kvalitetnejši, a z enakim vodnim znakom označeni papirni masi separatov nemške arije Ergiesse mein Mund (NmF, Ms. mus. 52a). Identičen, a spet $\mathrm{v}$ drugačni papirni masi ${ }^{105}$ odtisnjeni vodni znak ima tudi ovojnica $\mathrm{z}$ isto pisavo (A) prepisane arije $O$ Jesu, Jesu $m i^{106}$ bavarskega skladatelja Isfrida Kayserja.

Drugo varianto Kumarjevega levčka (Sl. 5/b) zasledimo na naslovnici in separatih $^{107}$ nemške arije Sey gegrüst du Brun der Gnaden (NmF, Ms. mus. 52) ter na naslovnici prepisa Aumannove arije Sic a Deo bonoraris ${ }^{108}$, napisani $\mathrm{z}$ isto pisavo (A). Poleg vodnih znakov sta identični tudi papirni masi obeh zadnje omenjenih naslovnic ter papirna masa naslovnice prepisa Kayserjeve arije (konceptni papir) ${ }^{109}$. Papirna masa separatov druge od navedenih nemških arij je identična s separati latinskega dueta (pisarniški papir), povsem drugačno papirno maso in vodne znake pa imajo separati obeh prepisov (t. i. real-papir). Sodeč po skladnosti navpičnih črt in vodnega znaka $^{110}$ sta lista separatov Violino Secondo Kayserjeve in Violino Primo Aumannove arije najverjetneje dve strani iste papirne pole. Iz vsega sledi, da prvi in trije zadnje navedeni odtisi obeh variant Kumarjevega levčka, v sicer dveh različnih papirnih masah, po vsej verjetnosti izhajajo iz enega in istega kalupa-dvojčka.

Sočasno rabo obeh variant potrjujeta tudi G. Eineder, z navedbo enake letnice za začetek njunega pojavljanja (1771) ${ }^{111}$, in J. Šorn, ki slednje postavi že v leto 1769 , ko naj bi Kumar na Dunaj poslal v pregled 32 vzorcev svojega papirja.

Presenetljivo je, da je bilo v vsem pregledanem gradivu mogoče najti le en sam referenčni primer tega znaka. Enak vodni znak namreč vsebuje le še neko izročilno pismo $^{112}$, ki je bilo iz ljubljanskega škofovskega dvorca v Kamnik odposlano 19. septembra 1770. Omenjena letnica seveda vnovič pod vprašaj postavlja točnost datacij Einederjevega kataloga in potrjuje navedeno Šornovo.

3.3.6. Po dva identična, a medsebojno le enaka vodna znaka srca s križem (SI.

6) se nahajata na separatih dveh Zupanovih uglasbitev latinskih slavospevov

104 Naslovnica/Alto in Organo inicialki, Canto cel znak, Violino Primo spodnji del in Violino Secondo zgornji del znaka.

105 Od vseh treh je ta najslabša. Značilna je bila za t.i. konceptni papir: (Prim.: J. Šorn, Starejši mlini..., str. 99.)

$106 \mathrm{NmF}$, Ms. mus. 279.

107 Naslovnica cel znak, Canto Solo cel znak, Violino Primo inicialki, Violino Secondo zgornji del znaka.

$108 \mathrm{NmF}$, Ms. mus. 115a.

109 Vse in samo te tri naslovnice vsebujejo tudi poligram: J:V:D:M:B: / O:S:P:D:B: / M:

110 Gre namreč za tri na sredini dvolistne pole nahajajoče se polmesece (beneška manira označevanja real-papirja). Polovica njihovih krakov se nahaja na enem, polovica pa na drugem listu pole.

111 Pod kataloškima št. 980 in 981.

112 MAL, KAM 105/a. 1. 41. 
Jezusu: duetov Salve Jesu Pastor bone (NmF, Ms. mus. 53a $)^{113}$ in O Jesu, Jesu chare (NmF, Ms. mus. 53b) ${ }^{114}$. Čeprav tega vodnega znaka literatura izrecno ne navaja, pa ga lahko z gotovostjo pripišemo beljaškemu papirničarju Georgu Tenggu. Prvič, zaradi inicialk $\mathrm{v}$ njem (TG), ki lahko označujejo le njega ali južnega Tirolca Giacoma Testorija, ki pa je mlin v Roveretu ustanovil šele leta $1775^{115}$; in drugič, zaradi opazne navzočnosti drugega Tenggovega papirja pri nas, tudi $z$ inicialkami njegovega sina Ignaza Georga (I.G.T.) ${ }^{116}$.

Identične vodne znake kot papir prvega dueta vsebujeta dva anonimna rokopisa ${ }^{117}$ iz knjižnice novomeškega frančiškanskega samostana, napisna $\mathrm{z}$ isto pisavo (A), enake pa - prav tako s pisavo A napisani - fragment arije Vere pium portans ${ }^{118}$, ter trije dokumenti iz začetka 60 . let 18. stoletja v NŠAL: kapitalski popis in finančno poročilo kranjskogorske župnije iz leta $1760^{119}$, finančno poročilo kamniške župnije za obdobje od 24. aprila 1762 do 24. aprila 1763 (katerega je kot "geordneten kürchen Bropsten U:L:F: der Statt: Pfarr: kürchen zu Stain" izdelal Zupanov tast Valentini Francisci Götzl) ${ }^{120}$, in slednjemu podoben Glavarjev dokument, nastal v Komendi leta $1765^{121}$.

3.3.7. Kot že pri prejšnjem, lahko tudi pri naslednjem vodnem znaku (Sl. 7) izvor določimo le posredno. Gre za znak grba s črko $\boldsymbol{X}$ in od njega ločeni inicialki FW. Nahaja se na Zupanovi antifoni Regina coeli in A (NmF, Ms. mus. 48d) ${ }^{122}$. Starejšo varianto tega znaka (z zašiljenim vrhom bočnih krakov) srečamo na nekem upravnem aktu ${ }^{123}$ kranjskogorske župnije iz leta 1727 ter kamniški knjigi mašnih beneficijev $^{124} \mathrm{z}$ uvodnikom, datiranim s 24 . aprilom 1743. Ta poleg omenjenega znaka

113 Naslovnica/Alto levo polovico, Canto desno polovico, Organo levi spodnji del polovice in Violino Primo desni spodnji del polovice vodnega znaka.

114 Alto desno polovico, Canto levo polovico, Violino Primo levi spodnji del polovice in Violino Secondo levi zgornji del polovice vodnega znaka.

115 Prim.: Eineder, The ancient Paper-Mills..., str. 99.

116 Gre za papir, ki ga zaznamuje znak konjička ter kot pri obravnavanem vodnem znaku oblikovani inicialki GT (Eineder, št. 738). Zaslediti ga je mogoče na rokopisni zbirki liturgičnih skladb iz novomeškega frančiškanskega samostana (NmF, Ms. mus. 93); vezavi separatov Basso in Violino 2 do zbirke Octo Missae p. Lamberta Krausa iz leta 1762 v komendski knjižnici P. P. Glavarja; in na vezavi knjige Das brochne Brod (Augsburg, 1760) iz iste knjižnice. Inicialke I.G.T. se v pregledanem gradivu prvič pojavijo leta 1769 , na že omenjenem finančnem poročilu kamniške župnije. (Gl. op. 67.)

117 Arija Quando cessabis a malo o chara (NmF, Ms. mus. 116a) in fragmentarno ohranjen spev Ad coenam Agni providi (NmF, Ms. mus. $116 \mathrm{c})$.

118 Separat Canto, NmF, Ms. mus. 141d.

119 NŠAL, Kranjska Gora, Razne listine 18. stol. in zač. 19. stol., f. 2.

120 Zelendte Rattung, NŠAL, Kamnik, Razne knjige, f. 2. Prim. tudi op. 67.

121 Zapiski dohodkov in izdatkov pri župni cerkvi v Komendi in njenih podıužnicah, 1751-1765 (NŠAL, Komenda, f. 3/1).

122 Naslovnica/Violino Primo cel znak, Canto Primo spodnji del znaka, Organo zgornji del znaka, Canto secondo zgornji del inicialk, in Violino Secondo spodnii del inicialk.

123 NŠAL, Kranjska Gora, Razne listine 18. stol. in zač. 19. stol., f. 2.

124 NŠAL, Kamnik, Ustanovne maše 1743-1768. 
vsebuje še neki sicer povsem drugaそen vodni znak, a z inicialkama GW. Najstarejši pojav inicialk FW (ob grbu s poštnim rogom) v pregledanem gradivu razkriva že omenjeni Glavarjev Status animarum iz leta 1754, najstarejši pojav skoraj enake variante obravnavanega znaka $\mathrm{z}$ inicialkama $\mathrm{FW}$ pa kranjskogorska poročna knji$\mathrm{ga}^{125}$ iz leta 1755. Njej enaka, med seboj neidentična vodna znaka vsebujejo še: naslovnica in Organo separat zbirke Responsoria Pro Quatuor Matutinis (1759) ter zbirka božičnih jutranjic iz ljubljanske stolnice, napisana $\mathrm{z}$ isto pisavo, ter neko izročilno in poročno pismo ${ }^{126}$, datirano z 31. januarjem $1759 \mathrm{v}$ Kamniku.

Povsem enak vodni znak prinašajo trije orgelski fragmenti, napisani s pisavo B. Prva dva ${ }^{127}$ sta izpadla lista iz - po notnem črtovju sodeč - dveh različnih zbirk liturgičnih skladb iz novomeškega kapitlja, tretji, Canto Solo separat arije Dove si vidde mai ${ }^{128}$, se nahaja $\mathrm{v}$ knjižnici novomeškega frančiškanskega samostana. (Zaradi slabšega odtisa vodnega znaka vseh treh muzikalij identitete ni moč ne potrditi ne zavreči.)

V času uporabe papirja s tem vodnim znakom sta na šiš̌em habsburškem ozemlju delovala le dva papirniška mlina, ki sta svoje proizvode označevala $z$ inicialkama FW. Rannersdorfski mlin v Spodnji Avstriji, čigar lastništvo je leta 1763 nasledil Franz Anton Würtz, sin Franza Alexandra ${ }^{129}$, in koroški mlin v Šentrupertu pri Celovcu, ki je po letu 1722 prešel v last papirniškega mojstra Georga Weinländerja. G. Eineder v kratkem orisu zgodovine tega mlina kot leto uradnega prenosa njegovega lastništva na zakonca Franza in Anno Weinländer navede letnico 1771, vendar $s$ tem še ne izključuje uporabe inicialk FW že pred omenjenim prevzemom. Iz vsega potemtakem ni težko zaključiti, da obravnavani papir najverjetneje izvira iz Weinländerjevega mlina na Koroškem.

3.3.8. Na prvem izmed neidentificiranih vrst papirja novomeških rokopisov Zupanovih arij in duetov sta zapisani nemška arija Maria wer dich kennet (NmF, Ms. mus. 52d) ${ }^{130}$ in naslovnica neohranjene antifone Salve Regina in $A$ (NmF, Ms. mus. 48). Enak vodni znak kot nemška arija, poštni rog s krono in inicialkama AG (Sl. 8/a), v pregledanem gradivu vsebujeta le še oba Clarino separata Misse Pastorale in $\mathrm{D}^{131}$ neznanega skladatelja, hranjene v knjižnici novomeškega kapitlja.

125 NŠAL, Kranjska Gora, Poročne knjige, 1755-1784.

126 MAL, KAM 105/a. 1. 40.

127 NmKap, Ms mus. 3 in 4.

$128 \mathrm{NmFr}$, Ms. mus. 57a.

129 Prim.: G. Eineder, The ancient Paper-Mills..., str. 50.

130 Naslovnica/Canto Solo cel znak, Organo celi inicialki AG, Violino Primo zgornji del inicialk, ter Violino Secondo in Alto Viola spodnji del inicialk.

131 NmKap, Ms. mus. 8. 
Rokopis je napisan $\mathrm{v}$ pisavi $\mathrm{B}$ in je nedatiran, vendar kar trije vodni $\mathrm{znaki}^{132}$ preostalih separatov kažejo na to, da po vsej verjetnosti ni mogel nastati pred začetkom 80. let 18. stoletja.

Večjo varianto inicialk AG (Sl. 8/b) poleg omenjene naslovnice prinašata še $z$ isto pisavo napisana fragmenta ${ }^{133}$ neznane arije $\mathrm{v}$ novomeškem frančiškanskem samostanu. Vsi trije odtisi so identični in navzoči na isti papirni masi.

V pregledanem gradivu zasledimo še dva - med seboj identična - primera sicer drugačnega vodnega znaka, a z enako oblikovanima inicialkama AG. Prvi je na papirju Ivančičevih Lytaniae Lauretanae ex $C^{34} \mathrm{v}$ novomeškem frančiškanskem samostanu, drugi pa na najverjetneje pozneje priloženih in $s$ pisavo $F$ napisanih godalnih separatih Pichlovega Offertorium Festivum in $C$ iz ljubljanske stolnice.

3.3.9. Naslednji po izvoru nedoločen vodni znak (Sl. 9) se nahaja na Zupanovem latinskem duetu Jesu dulcis memoria (NmF, Ms. mus. 51a) ${ }^{135}$. Motiv lilije je bil poleg poštnega roga in šesterokrake zvezde skozi celo 17., 18. in prvo polovico 19. stoletja najpogosteje uporabljeni "emblem" papirničarjev po vsej Evropi. Zato že vsaka nejasnost glede pripadajočih inicialk povsem onemogoči možnost njegove identifikacije.

3.3.10. Ob koncu predstavitve rezultatov papirološke študije s pisavo A napisanega dela rokopisov Zupanovih skladb je potrebno izmed vseh $\mathrm{z}$ njo povezanih in datacijsko določnih vodnih znakov omeniti še najmlajšega. Nahaja se na anonimnem fragmentu arije Ora absolutaria ${ }^{136}$, hranjenem v notni zbirki novomeškega frančiškanskega samostana. Enak vodni znak samoroga z inicialkami I.G.T. srečamo že na Anwiederruflicher Lauff Brieff ${ }^{37}$, datiranem s 1. junijem $1781 \mathrm{v}$ Komendi, identičen pa na finančnem poročilu ${ }^{138}$ kamniške župnije za leto 1785. Redek primer dveh tudi po deformaciji odtisa identičnib vodnih znakov razkrivata prvi tu omenjeni in vodni znak notranje pole separata Organo Misse Pastorale in $D^{139}$ iz novomeškega kapitlja, napisane s pisavo B.

3.3.11. Pisava A ne izkazuje razvidnejše kronološke diferenciacije, saj obe "varianti" te pisave ( $\mathrm{z}$ bolj in manj zaokroženimi velikimi začetnicami) nastopata v večjem delu muzikalij sočasno. Opazno je le nekoliko izrazitejše pojavljanje prve od

\footnotetext{
132 Kumarjeva mlajša varianta velikonočnega jagnjeta (gl. op. 94), Tenggov samorog z inicialkami I.G.T. (gl. op. 137-39) in Kienmoserjeva najmlajša varianta kovača (Eineder, št. 760, leto 1779).

133 Signirana posebej: NmF, Ms. mus. 141/d in 485.

134 Nekdaj v lasti p. Mavricija Pöhma, NmF, Ms. mus. 54 a.

135 Naslovnica/Alto cel znak, Organo zgornji del in Violino Secondo spodnji del znaka.

136 Separata Canto Primo in Canto Secondo. NmF, Ms. mus. 454.

137 NŠAL, Komenda, Listine 18. stol., f. 16/3.

138 NŠAL, Kamnik, Razne knjige, f. 1.

139 Gl. op. 131.
} 
njiju na rokopisih, ki uporabljajo Müllerjev papir z vodnimi znaki manjšega in večjega samoroga.

3.4.0. Pisava $\mathbf{B}$ je $\mathbf{v}$ notnem delu pregledanega gradiva ob številnih drugih najobsežneje zastopana. Poleg Zupanovih Litaniae Lauretanae (NmKap, Ms. mus. 61), njegove Regine Coeli/Salve Regina in separatov Misse ex C (NmKap, Ms. mus. 60) je v obeh novomeških notnih zbirkah zaslediti še devetnajst v celoti in šest fragmentarno ohranjenih rokopisov skladb $s$ to pisavo ${ }^{140}$. Nekaj njih ${ }^{141}$ na spodnjem desnem kotu naslovnice prinaša ime Andreja Pittra ${ }^{142}$. Večina tistih, ki se nahajajo v frančiškanski knjižnici, pa prek zbrisanega Pittrovega imena še - najverjetneje $s$ Pöhmovo roko zapisani - zaznamek: Ad S.U. P. Mauritii OMR. ${ }^{143}$ Kar pomeni, da so ti bili pozneje v uporabi patra Mavricija Pöhma ${ }^{144}$.

Glede na aktualnost in izvor določnih vodnih znakov rokopisov z obravnavano pisavo bi le-to kazalo okvirno postaviti v obdobje poznih 50. ali zgodnjih 60. let (grb s črko $X, \mathrm{FW})^{145}$, kontinuirano v 60. in 70. leta (Kienmoserjeva starejša varianta kovača, ter jelenček, poštni rog in kača na križu iz 1771 Dizme Nikla) ${ }^{146}$, pa vse do poznih 80 . let 18. stoletja (Kumrovo mlajše velikonočno jagnje ${ }^{147}$, že omenjeni samorog Ignaza Tengga ${ }^{148}$ in krona s stiliziranimi inicialkami ICVS $^{149}$ ).

3.4.1. Vodni znak obeh omenjenih Zupanovih skladb, kovača $\mathrm{z}$ inicialkama IK (Sl. 10), v pregledanem vzorcu referenčnega gradiva srečamo sorazmerno velikokrat. Redkeje zasledimo njegove - po razvoju likovnih značilnosti sodeč - mlaj$\check{s}$ in starejše oblikovane variante, a vse le v novomeških zbirkah muzikalij. Tudi drugega papirja istega proizvajalca drugod praktično ni bilo zaslediti. Edini nen-

140 NmKap, Ms. mus. 3, 4, 8, 24, 26, 57 in NmF, Ms.mus. 57a, 113a, 113b, 118a, 118b, 119, 122a, 122b, 127, 128, 132, 133, 136, 280, 283a, 283b, 284, 289a, 445 .

141 NmKap, Ms. mus. 61 in NmF. Ms. mus. 113a, 118b..

142 Osebnost Andreja Pittra doslej še ni razjasnjena. Janez Höfler domneva, da gre za enega tedanjih novomeških organistov. (Prim.: Janez Höfler, Glasbenozgodovinske najdbe XVIII. in XIX. stoletja v Novem mestu, Kronika, XV/1967, št. 3, str. 137.)

$143 \mathrm{NmF}$, Ms. mus. 113b, 119, 283a, 283b, 284, 289a. Na naslovnici Arie de Immaculate (NmF, Ms. mus. 114b) je kot oznaka avtorstva z isto pisavo napisana abreviatura p. Mavricija Pöhma (Autb: P:M:P:F:).

144 P. Mavricij Pöhm (1745 ? - 1803), organist, gvardijan frančiškanskega samostana v Novem mestu ter profesor in pozneje prefekt samostanske gimnazije. Prišel je s češkega pred letom 1774. Po Höflerjevem mnenju gre za osrednjo osebnost novomeškega frančiškanskega samostana druge polovice 18. stoletja, ki mu lahko pripišemo zasluge za razcvet glasbenega poustvarjanja $\mathrm{v}$ tem času. (Prim.: J. Höfler, ibid., str. 136.)

145 Gre za že omenjene tri fragmente: NmKap, Ms. mus. 3, 4 in NmF, Ms. mus. 57a.

146 NmKap, Ms. mus. 26 in Nmf, Ms. mus. 113a, 119, 128, 133. Prim.: J. Šorn, Starejši mlini..., str. 115.

147 Nahaja se na naslovnici in večini separatov prepisa Sinfonie in D Niccoloja Piccinnija (NmF, Ms. mus. 284), na nekaterih separatih Misse Pastorale in D (NmKap, Ms. mus. 8) in naslovnici prepisa neke Umlauffove arije (NmF, Ms. mus. 113b; separati so napisani na pozneje obravnavanem beneškem real-papirju $\mathrm{z}$ inicialkami GFA, gl. op. 157). Identičen vodni znak vsebujejo notranji listi komendskega Status animaıum iz leta 1786 (hranjenega v župnišču v Komendi).

148 Nahaja se na notranjih listih Organo in Basso separatov Misse Pastorale in D (NmKap, Ms. mus. 8). Gl. op. 137-39.

$149 \mathrm{NmKap}$, Ms. mus. 24 in NmF, Ms. mus. 127. G. Eineder začetek pojavnosti tega vodnega znaka (št. 470) datira z letnico 1780. V obravnavanem gradivu je enakega zaslediti na kamniškem Inventarium und Uibarium [...] De Anno 1785 (NŠAL, Kamnik, Inventarij in Urbarij $1785)$. 
ovomeški primer papirja Johanna Kienmoserja ${ }^{150}$ ( $\mathrm{z}$ znakom poštarja na konju ${ }^{151}$ in značilno oblikovanima inicialkama IK) je dvolistni orgelski fragment maše v ljubljanski stolnici, s pripisom: Del Novotni. 1771.

Čeprav niti literatura niti preučeni viri ne posredujejo eksplicitne informacije o dataciji obravnavanega vodnega znaka, pa je z rekonstrukcijo relativne kronologije in časovnega konteksta variant $\mathrm{v}$ njej vseeno mogoče vsaj okvirno določiti časovne meje njegove aktualnosti. Pri čemer oporo nudi tudi nekaj ohranjenih numeracij Pittrovih rokopisov, ki so bile, kot kaže, posledica kronološkega zapovrstja njihove izdelave ${ }^{152}$.

Najstarejšo varianto Kienmoserjevega kovača razkrivajo vokalni separati Scheiblove Missa ex $A$ major ${ }^{153}$, napisani s pisavo D. Eineder njegov začetek postavi v čas okoli leta 1750 (št. 757), vendar glede na druge vodne znake ${ }^{154}$ Scheiblovega rokopisa ni mogoče, da bi ta nastal pred prvo polovico 60. let 18 . stoletja.

Obravnavanemu vodnemu znaku oblikovno bližja je njegova druga starejša varianta, ki se nahaja na papirju s pisavo B prepisanega Vanhalovega Divertimenta in $B^{155}$ (numeriran s številko 5), ki je pozneje, kot kaže, iz Pittrove prešel v Pöhmovo uporabo.

Oblikovne poteze te in naslednje variante (iz leta 1779) navajajo $\mathrm{k}$ domnevi, da gre vodni znak kovača, kot ga prinašata oba novomeška rokopisa Zupanovih večstavčnih skladb, kronološko postaviti med njiju. Kljub temu, da s pisavo B napisani rokopis Wernerjevih Litaniae Lauretanae in $C^{56}$ poleg dveh različnih odtisov variante iz konca 70 . let na separatih Oboe $1 \mathrm{mo}$ in 2 do vsebuje tudi njemu enakega, ter, da je $\mathrm{z}$ njim označeni papir moral v Novem mestu biti aktualen vsaj $\mathrm{v}$ istem času, če ne še pozneje, kot neki drugi v letih 1781 in 1782 . Gre namreč za

150 Kienmoserjevo lastništvo t. i. Steyr-Altmüble (gre za najstarejši mlin Zgornje Avstrije iz ok. 1550) sega v leto 1750 . Trajalo je vse do njegove smrti nekje med letoma 1779 in 1783 , ko se je njegova žena drugič poročila $z$ Johannom Georgom Jocherjem. (Prim.: G. Eineder, The ancient Paper-Mills..., str 64.)

151 Od petih Kienmoserjevih variant tega znaka, ki jih prinaša Einederjev katalog, je ta najbližja varianti št. 774, s pojavom leta 1773.

152 Gre za devet v celoti ohranjenih numeracij na zgornjem desnem kotu - s pisavo B napisanih - naslovnic (N. 1, N. 4, N. 5, N. 24, N. 27, N. 30, N. 45, N. 49, N. 59) in eno delno ohranjeno na zgornji desni strani prvega lista Organo separata Zupanove Misse ex $C$ (N. 4[?]), ki pa je skoraj zagotovo številka 44. (NmF, Ms. mus. 283a, 283b, 119, 118b, 113a, 280, 284 in NmKap, 60, 61.)

Zapovrstje številk se namreč povsem ujema z zapovrstjem aktualnosti vodnih znakov papirja, ki ga te numerirajo: N. 1 in N. 4 imata med seboj identični in le pri njiju opažen papir ( $\mathrm{z}$ oznako za t.i. real-papir in inicialkama AF ter florirano vinjeto nad njima); $\mathrm{N}$. 5 vsebuje dizugo najstarejšo varianto kovača Johanna Kienmoserja; N. 27 kačo na križu in poštni rog Dizme Nikla; N. 30 in N. $4[4$ ?] obravnavanega kovača Johanna Kienmoserja; N. 49 enakega kovača in Kumarjeve tri polmesece, z enako oblikovanima inicialkama TC, kot jih vsebuje njegov poštni papir iz začetka 80. let (Eineder, št. 1388); in N. 59 Kumarjevo mlajše velikonočno jagnje (1786, gl. op. 94).

153 Gl. op. 78 .

154 Gre za znaka $S v$.Vida z inicialkami ICVS (SI. 2/b) in - v nadaljevanju obravnavani - grb z dvoglavim orlom in inicialkami I.I.K., ki ga Eineder datira z letnico 1766 (št. 391). Skoraj identični vodni znak se v pregledanem gradivu nahaja na kranjskogorski cerkveni listini Cession, und l...?] Quitung iz 28. junija 1766 (NŠAL, Kranjska Gora, Razne listine 18. stol. in zač. 19. stol., f. 2).

$155 \mathrm{NmF}$, Ms. mus. 119.

156 Hranjenih v novomeškem kapitlju, NmKap, Ms. mus. 57. 
t. i. real-papir neznanega beneškega proizvajalca ( $z$ inicialkami $G_{F A}{ }^{157}$ ), na katerem so - prav tako s pisavo B - prepisani vsi separati Gödlovih Lavretanskih litanij ${ }^{158}$ razen Clarina $1 m o$ in $2 d o$, ki sta na papirju Dizme Nikla, ter separata Tympano, ki ga zaznamuje enak Kienmoserjev kovač kot omenjeni Zupanovi skladbi. Beneškemu identični papir je namreč za prepis Sterklovih Sonates pour clavecin op. $2^{159}$ in Vanhalovih Lavretanskih litanij ${ }^{160}$ uporabil tudi pater Pöhm ${ }^{161}$, ki je ob koncu prvega še dopisal: Finis 1782, pod drugega pa: Finis 1781. Izpod iste roke nastala sta tudi prepisa šestih Vanhalovih Duetov op. $23^{162}$, izšli na Dunaju leta 1780 , in fragmentarno ohranjenega Tantum erga ${ }^{163}$ neznanega skladatelja, oba na papirju z identičnim Kienmoserjevim kovačem, kot ga vsebuje tolkalni separat Gödlovih Lavretanskih litanij. (Identične vodne znake imata še dva rokopisa novomeškega frančiškanskega samostana: s pisavo B prepisan Quarteto a Clarinetto, Violino, Viola et Violoncello ${ }^{164}$ Carla Stamiza ter naslovnica in Basso separat anonimne arije ${ }^{165}$, nekdaj v lasti patra Pöhma.)

Precej drugačen odtis obravnavanega znaka prinašata $s$ pisavo $B$ prepisana Razelspergova Cassatio in $D^{166}$ (numerirana s številko 49) in še ena Gödlova uglasbitev Lavrentanskih litanij ${ }^{167}$. (Ovitek k Gödlovi skladbi je, kot kaže, izdelal pater Pöhm, vsebuje pa Thalbergov vodni znak škofa $s$ palico ${ }^{168}$, ki je po Einederjevih datacijah sodeč v obtoku bil med letom 1774 in začetkom 80. let 18. stoletja, ko ga je nasledila nekaj let mlajša varianta.) Po znaku skoraj identičen, a v razmaku vertikalnih črt papirne mase le enak odtis prinaša fragmentarno ohranjeni rokopis Lavretanskih litanij ${ }^{169}$ neznanega skladatelja, nastal izpod peresa Mavricija Pöhma,

157 Prim.: Eineder, The ancient Paper-Mills..., št. 498 in št. 503. Obe varianti inicialk datira z letnico 1785.

158 Hranjene $v$ knjižnici novomeškega frančiskanskega samostana, NmF, Ms. mus. 122b.

$159 \mathrm{NmF}$, Ms. mus. 290. Izdane na Dunaju ok. leta 1775.

160 Ohranjene fragmentarno pod signaturami: separata Basso in Tenore NmF, Ms. mus. 167, Oboa 2do NmF, Ms. mus. 148a, in Organo NmF, Ms. mus. 446 .

161 Gre namreč za isto pisavo kot jo srečamo na številnih že omenjenih zaznamkih: Ad S.U. P. Mauritii OMR., in na že omenjeni Ariji s signaturo NmF, Ms. mus. 114b. (Prim. op. 143.)

$162 \mathrm{NmF}$, Ms. mus. 291

$163 \mathrm{NmF}$, Ms. mus. 142

$164 \mathrm{NmF}$, Ms. mus. 289a.

$165 \mathrm{NmF}$, Ms. mus. 115b.

$166 \mathrm{NmF}$. Ms. mus. 280.

$167 \mathrm{NmF}$, Ms. mus. 122a.

168 Prim.: Eineder, The ancient Paper-Mills..., št. 748. Identičen vodni znak vsebuje - s pisavo D napisana - naslovnica Misse ex $D$ de B:M:V Carola Loosa (NmF, Ms. mus. 130). Gl. op. 193.

169 Gre za dva z različnimi signaturami ohranjena separata v knjižnici novomeškega frančiškanskega samostana: Organo Concerte (NmF, Ms. mus. 129/b) in Basso (NmF, Ms. mus. 148). 
slednjemu identičnega pa separati ${ }^{170}$ obeh zadnje omenjenih Zupanovih skladb, numerirani s številkama 30 (Litaniae) in 44 (Missa).

Dva različna odtisa ${ }^{171}$ mlaǰ̌e izmed $\mathrm{v}$ Einederjevemu katalogu prikazanih variant Kienmoserjevega kovača (št. 760), s slogovno spremenjenima inicialkama I.K. ${ }^{172}$, vsebujeta že navedeni skladbi iz novomeškega kapitlja: Missa Pastorale in D ter prepis Wernerjevih Litaniae Lauretanae in $C^{73}$. Glede na Einederjevo datacijo začetka njene uporabe - leta 1779 - in Kienmoserjevo smrt - pred letom $1783^{174}$ - kaže omenjeno varianto postaviti na konec trideset let trajajočega razvoja tega znaka. Kar nenazadnje potrjujejo tudi nekatere iz te raziskave izhajajoče ugotovitve: prvič, papirja z oznakami Johanna Kienmoserja na mlajših rokopisih ni več zaslediti; in drugič, vodna znaka separatov Misse Pastorale in D, Kumarjevo mlajše velikonočno jagnje in samorog Ignaza Tengga, ki nastopata hkrati $\mathrm{z}$ obravnavanim znakom, svojo aktualnost izkazujeta za prvo polovico in sredo 80. let 18. stoletja, pri čemer prvi izmed njiju zaznamuje tudi separate prepisa Piccinnijeve Sinfonie in $D^{175}$, numeriranega s številko 59.

3.5.0. V nasprotju $\mathrm{s}$ prejšnjima je pisavo $\mathrm{C} v$ pregledanem gradivu redko zaslediti. Poleg nepopolno ohranjenih Te Deumov Jakoba Zupana in Ägidija (?) Schenka se $\mathrm{v}$ notnem arhivu ljubljanske stolnice nahajata le še dva neidentificirana fragmenta Te Deuma in štirih Tantum ergo v značilnem kaligrafskem tipu ter že omenjeni orgelski separat Novotnijeve Maše iz leta 1771 z uporabnim tipom te pisave. Novomeška knjižnica frančiškanskega samostana hrani dva primera pisave C: kaligrafsko izpisani fragment posvetne arije Non so' se tu m'intendi ${ }^{176}$ in tipološko mešani violinski separat nekega večstavčnega instrumentalnega dueta ${ }^{177}$.

(V vokalnih separatih Zupanovega Te Deuma je regularnemu besedilu stavka Salvum fac s povsem drugačno pisavo (F) dopisan še dvovrstični verz Te ergo quesumu. Gre za oblikovno precej samosvojo in po načinu uporabe nekako "dopolnjujočo" pisavo iz ljubljanske stolnice s konca 18. stoletja. Pretežno jo je namreč zaslediti le na separatih in naslovnicah, dodanih $\mathrm{k}$ starejšim rokopisom, na primer

\footnotetext{
170 Litaniae in G: Canto in Alto cel vodni znak, Tenore in Violino Primo inicialki, Basso in Organo cel znak. Missa ex C: Canto obligato in Basso obligato cel vodni znak in znak, Violino Primo, Violino Secondo in Organo cel vodni znak in inicialki, Clarino Primo in Clarino Secondo cel vodni znak.

171 Ta odtisa, ki se hkrati nahajata na separatih prepisa Wernerievih Litaniae Lauretanae (NmKap, Ms. mus. 57), po vsej verjetnosti izhajata iz t.i. kalupa-dvojčka.

172 Oblikovno zelo podobno slogovno spremembo $\mathrm{v}$ istem času doživijo tudi inicialke I.I.K., ki pripadajo mlajši varianti - v nadaljevanju obravnavanega - znaka grba z dvoglavim orlom. Gl. op. 187.

173 NmKap, Ms. mus. 8 in 57.

174 Gl. op. 150.

$175 \mathrm{NmF}$, Ms. mus. 284. Gl. op. 94 in 137-39.

$176 \mathrm{NmF}$, Ms. mus. 476.

$177 \mathrm{NmF}$, Ms. mus. 147.
} 
na Canto separatu k zgoraj omenjenemu fragmentu Te Deuma (napisanem s pisavo C), na godalnih separatih v ovitku Maše Pro Ressurectione Domini Johanna Hoffmanna (edinem primeru pisave D iz notnega arhiva ljubljanske stolnice) ${ }^{178}$, ali na naslovnici Misse brevis in dis Pellegrina Dalfiume, ki pod specifikacijo instrumentarija in navedbo avtorja posreduje tudi datum: decembre 1790..)

3.5.1. Poleg treb polmesecev (Sl. 15), ki ne označujejo izvora, temveč le kakovostni razred (real-) papirja, in nejasnega odtisa neidentificiranega znaka (Sl. 13), vsebuje stolnični rokopis Zupanovega Te Deuma še dva glede porekla tudi ne povsem pojasnjena, vendar za datiranje njegovega papirja uporabna vodna znaka (Sl. 12 in 14).

3.5.2. Kljub precejšnjemu številu pri nas nastalih dokumentov iz 60., 70. in prve polovice 80 . let 18. stoletja $\mathrm{z}$ inicialkami IIK in znakom grba $z$ dvoglavim orlom, ter kljub Einederjevi navedbi njegovega "kranjskega" izvora" ${ }^{179}$, Jože Šorn v svoji študiji mlinov za papir tega znaka ne omeni, niti mlina ali mojstra, ki bi ju navedene inicialke lahko označevale.

Izmed šestih $\mathrm{v}$ raziskavi ugotovljenih variant tega znaka Einederjev katalog vključuje le starejši dve. Najstarejšo izmed njiju (št. 391) datira z letom 1766, vendar bi glede na referenčna dokumenta ${ }^{180}$ iz Komende, nastala leta 1762, kazalo njen začetek brez dvoma pomakniti v starejši čas.

Vodni znak dvolistne ovojnice Zupanovega Te Deuma (Sl. 12), mlajše variante ${ }^{181}$ predhodnega, ponuja skupaj s štirimi različnimi odtisi njemu enakih vodnih znakov iz pregledanega gradiva natančen vpogled v starost papirja, ki ga zaznamuje. Povsem identičen, vendar slabši - glede na stopnjo deformacije torej mlajši odtis je zaslediti na neki $s$ komendskim župnikom v Mekinjah sklenjeni pogodbi ${ }^{182}$, $\mathrm{z}$ dne 4. januarja 1771. Obsežno uporabo obravnavanega papirja $\mathrm{v}$ prvi polovici 70. let 18. stoletja nenazadnje potrjujejo tudi trije različni, približno $z$ enoletnim zamikom sledeči si odtisi enakega znaka iz kranjskogorskega župnijskega arhiva ${ }^{183}$ (na papirju ženitnega pisma iz 17. februarja 1773, zadolžnice iz 28. marca 1774 in

$178 \mathrm{Ki}$ tudi edini v notnem delu pregledanega gradiva vsebuje neidentificirani vodni znak grba s helebardami in inicialkami IGE. Enaka je zaslediti še na kamniški Krstni knjigi iz leta 1753 (NŠAL, Kamnik, Krstne knjige, 1753-1760), testamentu nekega Primasa Leebitscha, datiranem s 15. januarjem 1754 v Komendi, ter pogodbi, sklenjeni v Komendi 24. januarja 1754 (NŠAL, Komenda, Listine iz 18. stol., f. 16/3). Gl. op. 195.

179 Eineder, št. 392.

180 Prvi je nastal izpod roke Jožefa Tomlja v Komendi 29. januarja 1762 (NŠAL, Komenda, Jožef Tomelli, f. 19/7). Drugi je t.i. Lauff Brieff, poslan iz Križ v Komendo 14. maja 1762 (NŠAL, Komenda, Listine iz 18. stol., f. 16/3). Poleg njiju je bilo v pregledanem gradivu zaslediti še štiri primere te variante: prvi je na Organo separatu že omenjenega prepisa Scheiblove Misse ex A major; napisanem $s$ pisavo D (NmF, Ms. mus. 123); drugi na prostih listih vezave učbenika Fundamenta v novomeškem frančiškanskem samostanu (NmF, Ms. mus. 511), tretji na pismu Josepha Suppana (vicari zu Pfarboff Zirklab [Cerklje na Gorenjskem]), poslanem v Komendo 29. marca 1766 (NŠAL, Komenda, Listine iz 18. stol., f. 16/3), četrti in s tretjim identičen pa na kranjskogorskem Cession, und [...?] Quitung iz 28. junija 1766 (NŠAL, Kranjska Gora, Razne listine iz 18. stol. in zač. 19. stol., f. 2).

181 Eineder, št. 392. Datiran z letnico 1771.

182 NŠAL, Komenda, Listine iz 18. stol., f. 16/3.

183 NŠAL, Kranjska Gora, Razne listine 18. stol. in zač. 19. stol., f. 2. 
pobotnice iz 16. januarja 1775) ter trije primeri njegove mlajše variante iz druge polovice 70-let (na papirju neke pogodbe ${ }^{184}$, sklenjene 30 . oktobra $1775 \mathrm{~V}$ Komendi, aktu ${ }^{185}$ kranjskogorske župnije iz 22. maja 1777, in na Glavarjevem pis$\mathrm{mu}^{186}$, poslanem iz gradu Lanšprež 22. aprila 1779).

Še mlajši varianti obravnavanega znaka sta kot kaže v obtok prišli kmalu po letu $1780^{187}$. Eno od njiju je zaslediti na naslovnici, najverjetneje izpod Pöhmovega peresa nastalega prepisa Pleyelevih Six Quatuors op. $I^{188}$, ki so v tisku izšli med letoma 1782 in 1783.

3.5.3. Inicialki AO s stilizirano floracijo nad njima (Sl. 14) se pojavita na dveh izmed separatov ${ }^{189}$ Zupanovega Te Deuma, razen tega pa le še na papirju rokopisne zbirke ${ }^{190}$ preprostejših liturgičnih skladb v novomeškem frančiškanskem samostanu: Variae Cantilenae ad Simplicem Usum V.P. Callisti Weibl / 1775. Navedena letnica in oblika inicialk ${ }^{191}$ navajata $\mathrm{k}$ domnevi, da gre $\mathrm{v}$ obeh primerih za papir češkega mlina Bensen, ki je bil med letom 1770 in $1790 \mathrm{v}$ lasti Antona Ossendorfa.

3.6.0. Pisavo D v obravnavanem opusu Zupanovih skladb razkrivata le naslovnica njegove Misse ex $C$ in Organo separat ohranjene Salve Regina. Podobna je pisavi A, vendar se od nje značilno razlikuje $z$ nekaterimi svojimi posebnostimi ${ }^{192}$. Povsem enakega videza kot naslovnica Zupanove maše sta tudi naslovnici že omenjenenih prepisov Scheiblove Misse ex A major (s kar štirimi v 60. letih 18. stoletja aktualnimi vodnimi znaki) in Misse ex $D$ de B:M:V Carola Loosa (s Thalbergovim škofom $s$ palico $^{193}$ iz leta 1774). Obe v spodnjem desnem kotu prinašata še zaznamek: $E: R$ : Joan: B: Heinrich Ricker ${ }^{194}$. Poleg njiju je v pregledanem gradivu najti še šestnajst v

184 NŠAL, Komenda, Listine iz 18. stol., f. 16/3.

185 NŠAL, Kranjska Gora, Razne listine 18. stol. in zač. 19. stol., f. 2.

186 NŠAL, Komenda, Listine iz 18. stol., f. 16/3.

187 Najstarejši dokument s slogovno precej spremenjeno podobo znaka in inicialk je najti na testamentu nekega Thomasa Mertla, sestavljenem v Kranjski Gori 13. oktobra 1780 (NŠAL, Kranjska Gora, Razne listine 18. stol. in zač. 19. stol., f. 2). Temu enake vodne znake pa še: na dopisu Deželnega glavarstva mestu Kamniku iz 1. maja 1781, na pritožbi krznarskega ceha kamniškemu mestnemu svetu in odgovoru nanjo iz 15. februarja 1782 in prošnji za sprejem v krznarski ceh iz 20. avgusta 1784 (MAL, KAM 117, 1 - 4) ter na neki pogodbi, sklenjeni v Kranjski Gori 23. februarja 1784 (NŠAL, Kranjska Gora, Razne listine 18. stol. in zač. 19. stol., f. 2).

$188 \mathrm{NmF}$, Ms. mus. 285.

189 Alto in Violino Primo.

$190 \mathrm{NmF}$, Ms. mus. 90.

191 Einederjev katalog prinaša le en primer inicialk AO (št. 1515). Označujejo češkega papirničarja Antona Ossendorfa. (Prim.: Eineder, The ancient Paper-Mills..., str. 114.)

$192 \mathrm{Na}$ primer po drugače oblikovanih osminskih pavzah, basovskih ključih, neuporabi kurzorjev, vinjetah ob koncih stavkov, značilnih kaligrafskib variantah velikih črk $\mathrm{A}$ in $\mathrm{C}$, idr., pa tudi po manj poševni in bolj raztegnjeni pisavi v celoti.

193 Eineder, št. 748. Gl. op. 168.

194 Verjetno frančiškanski pater v novomeškem samostanu. 
celoti in fragmentarno ohranjenih primerov ${ }^{195}$ te pisave (nekaj teh je prav tako označenih $\mathrm{z}$ Rickerjevim imenom), $\mathrm{ki} \mathrm{V}$ primerjavi $\mathrm{z}$ drugimi muzikalijami novomeškega frančiškanskega samostana in ljubljanske stolnice vsebujejo večinoma neenake vodne znake. Takšni sta tudi starejša varianta St. Vida z inicialkama $\mathrm{WZ}^{106}$, ali pa $\mathrm{v}$ vsem pregledanem gradivu samo ob tej pisavi opaženi, značilno oblikovani inicialki IH z znakom personificiranega polmeseca ${ }^{197}$.

Posebej zanimiv primer obravnavane pisave so trije instrumentalni separati ${ }^{198}$ latinskega dueta Salve Salus mea Deus, ki dopolnjujejo s pisavo A napisana vokalna separata (Canto in Alto).

Datacijsko določni vodni znaki papirja rokopisnih primerov pisave D izkazujejo obseg svoje aktualnosti med sredo 50. (grb s belebardami $\mathrm{z}$ inicialkami IGE ${ }^{199}$ in stareǰ̌a varianta St. Vida $\mathrm{z}$ inicialkama $\mathrm{WZ}^{200}$ ) in drugo polovico 70 . let 18 . stoletja (Thalbergov škof s palico iz leta $1774^{201}$ ).

3.6.1. Vodni znak šesterokrake zvezde z inicialkama TC (Sl. 11) in njegovo manjšo varianto je najti na papirju številnih rokopisov obeh novomeških notnih zbirk. Povsem identičnega kot naslovnica Zupanove Misse ex $C$ vsebuje še nepopisana ovojnica separatov anonimne maše ${ }^{202} \mathrm{v}$ novomeškem frančiškanskem samostanu, napisana s pisavo $B$.

Glede na druge vodne znake, ki se pojavljajo ob njem, bi kazalo aktualnost tega znaka omejiti na obdobje med poznimi 60 . in zgodnjimi 80 . leti 18 . stoletja. Kar vnovič govori v prid domnevi, da najverjetneje označuje papir ajdovskega mlina Tomaža Kumarja.

3.7.0. Naslovnica Zupanovega latinskega dueta Sacris solemniis je po značilni papirni masi (opažena le pri njiju) in pisavi (pisava E) povsem enaka naslovnici arije Salve Virgo florens ${ }^{203}$ neznanega skladatelja, hranjeni $v$ novomeškem frančiškanskem samostanu, ki vsebuje enak vodni znak (sidra v krogu z inicialkami ITS)

195 V ljubljanski stolnici: naslovnica maše Pro Ressurectione Dominj Joanna Hoffmanna (gl. op. 178). V novomeškem frančiškanskem samostanu: NmF, Ms. mus. 49b, 50a, 50b, 50c, 113/c, 124, 140, 143, 227, 282, 442, 490, 504, 509, 510.

$196 \mathrm{NmF}$, Ms. mus. 50a, 113/c, 509 in 510 . Gl. op. 82.

$197 \mathrm{NmF}, \mathrm{Ms}$. mus. 49b, 50b, 50c in 124.

198 Violino Primo, Violino Secondo in Organo (NmF, Ms. mus. 50c).

199 Gl. op. 178.

200 Gl. op. 82.

201 Gl. op. 168 in 193.

$202 \mathrm{NmF}$, Ms. mus. 136.

$203 \mathrm{NmF}$, Ms. mus. 114a. V omenjenem ovitku se nahajajo vokalni separat Canto Solo, napisan s pisavo A, in štirje godalni separati, ki so najverjetneje nastali izpod peresa patra Pöhma (gl. op. 143 in 161). 
kot še vezava komendskega Status animarum ${ }^{204}$ za leta 1786-1790 in neki cerkveni akt $^{205}$ kamniške župnije iz 14. julija 1803.

Pisavo E je zaslediti na številnih rokopisih ${ }^{206}$ obeh novomeških notnih zbirk, katerih vodni znaki so zaznamovali papir prvih desetletij 19. stoletja. Kar osem njihovih naslovnic pa v spodnjem desnem kotu prinaša še zapis: Eng: Jos: Kretschy [Kregzy, Kregczy] $]^{207}$.

\section{Izsledki raziskave:}

4.0. Predstavljeni rezultati papirološke in grafološke študije rokopisov Zupanovih skladb poleg odgovorov, ki s svoje strani prispevajo k reševanju uvodnih vprašanj, pred nadaljnje raziskave skladateljevega dela polagajo še nekaj koristnih spoznanj. Prvič; del opusa Zupanovih skladb, ohranjen v novomeškem frančiškanskem samostanu, je kot kaže avtografski. Drugič; sočasnost stikov kar petih z njim povezanih in $\mathrm{v}$ različnih krajih ali ustanovah skupaj nastopajočih pisav dokazuje razvejano komunikacijo (med osebami) institucij, ki so v drugi polovici 18. stoletja kontinuirano oblikovale ton domače glasbene (po)ustvarjalnosti. Še več. Novomeški rokopisi cerkvenih Scheiblovih $\operatorname{skladb}^{208}$, napisani $\mathrm{z}$ isto roko kot naslovnici Zupanove in $\mathrm{v}$ ljubljanski stolnici hranjene Hoffmannove Maše, dajejo slutiti sodelovanje tedanjih glasbenih središč na Slovenskem tudi prek deželnih meja. Tretjič; intenzivnost prepletanj v obravnavanih zbirkah muzikalij izstopajočih pisav prav ob opusu Jakoba Zupana razkriva njegov vodilni pomen in obseg aktualnosti v glasbenem življenju na Kranjskem morda že v 60, zagotovo pa v 70. in prvi polovici 80 . let 18 . stoletja. Četrtič, in s slednjim tudi načelno povezana je precejšnja verjetnost obstoja Zupanovih avtografov $\mathrm{v}$ Novem mestu že pred iztekom 18. stoletja. Torej še pred prihodom Jožefa Antona Krejčija - avtorja ovitka k duetu Sacris solemniis - na mesto kapiteljskega organista leta 1817, k čemer navajajo izpod Pöhmove roke izšli godalni separati arije Salve Virgo florens, katere vokalni del je napisan s pisavo Jakoba Zupana ${ }^{209}$. In petič; najverjetneje v različnem času nastala zapisa orgelskega separata dueta O gloriosa Virginum potrjujeta možnost, da novomeški avtografi niso (bili) edini in s tem najstarejši izvodi vsebovanih Zupanovih skladb. (Pri čemer ne velja spregledati izvirnega Stiasnyevega poročila

204 Hranjen v župnišču v Komendi.

205 NŠAL, Kamnik, Razni spisi, f. 16.

206 Skupno na enajstih: NmKap, Ms. mus. 2, 14, 15, 17, 19, 26, 45, 54, in NmF, Ms. mus. 114a, 157.

207 Jožef Anton Krejči, rojen na Moravskem leta 1787. V času razpisa za mesto dekliškega učitelja in organista v Novem mestu leta 1817 je bil učitelj in organist v Gornjem Gradu. V Novem mestu je kot kapiteljski organist ostal vse do smrti leta 1830. (Prim.: J. Höfler, Glasbenozgodovinske najdbe..., str. 142.)

208 Razen v novomeški frančiškanski zbirki so skladbe Johanna Adama Scheibla izpričane le še v t.i. ptujski zbirki muzikalij iz srede in druge polovice 18. stoletja (hranjene v ptujski Študijski knjižnici).

209 Gl. op. 203. 
s konca minulega stoletja, da se je "še pred 15. leti [torej ok. 1880] $v$ Komendi dobilo jako veliko not za instrumentalne maše, podpisane $z$ imenoma Jakob Zupan in Josip Tomelli ${ }^{\text {'210 }}$.)

4.1. Papirološka raziskava rokopisov skladb Jakoba Frančiška Zupana je v svojem primerjalnem delu pokazala, da je $\mathrm{z}$ vidika starosti njihovega papirja mogoče na večino uvodnih vprašanj odgovoriti pritrdilno. Razkrila je realno možnost, da je Jakob Zupan nekaj svojih danes znanih skladb napisal že v 60. letih, druge v 70., nekaj - tudi slogovno naprednejših - pa že konec 50. let 18. stoletja. Prva takšnih je vsekakor latinski duet O gloriosa Virginum, ki bi glede na njen starejši (?) izvod orgelskega separata lahko nastala vsaj že leta 1759. Konec 50. oziroma v zgodnjih 60. letih tudi še Regina coeli in A ter dueta Salve Jesu Pastor bone in O Jesu, Jesu chare, okoli srede (1764) antifoni Regina coeli v G-duru in v celoti ohranjena Salve Regina, v poznejših v 60. letih pa duet Maria gustum sentio. Na prehodu v 70. leta so poleg Himnusa Egregie Doctor Paule lahko nastale tudi prve Zupanove uglasbitve nelatinskih besedil, dueta Mutter der Lieblichkeit in Nichts ist treus auf dieser Erden, kmalu po letu 1770 pa latinski duet Sacris solemniis ter nemški ariji Ergiesse mein Mund in Sey gegrüst du Brun der Gnaden. Mlajši, ob vstopu v 80. leta 18. stoletja aktualen papir je skladatelj uporabil za rokopis še ene svojih nelatinskih arij, Maria wer dich kennet, in za naslovnico neohranjene Salve Regina in A. Novomeška prepisa Zupanovih Litaniae in $G$ ter Misse ex $C$ bi, kot kaže, lahko nastala konec 70., zagotovo pa na začetku 80. let 18. stoletja, prepis v ljubljanski stolnici ohranjenega Te Deuma pa že nekaj mesecev pred začetkom leta 1771.

Kljub temu, da pravkar eksplicirana datacija rokopisov Zupanovih skladb ne presega meje zgolj realno možnega in svojo uporabno vrednost prepoznava le v (svojem) delu širše oprtega dokazovanja, pa velja vseeno in prav zato opozoriti še na dvoje nič manj eksaktnih informacij, ki že odmerjajo raven v njej verjetnega. Prvič; vodni znaki in papirne mase obravnavanih Zupanovih rokopisov izkazujejo med separati iste skladbe skoraj brezizjemno enovitost, med posameznimi skladbami pa precejšnjo raznolikost. In drugič; med vsem pregledanim gradivom je bilo najti en sam datirani primer papirja ${ }^{211}$, ki po času uporabe vidneje izstopa iz okvira svoje širše izpričane aktualnosti. To seveda pritrjuje v opombi navedeni LaRuejevi domnevi ${ }^{212}$, da so skladatelji tudi iz finančnega razloga papir zvečine kupovali sproti, pač glede na trenutno izkazane potrebe, vendar pa nikakor še ne dovoljuje, da bi sicer visoko mero s tem legitimirane verjetnosti papirološko utemeljene datacije rokopisov Zupanovih skladb zamenjali za zgolj iz te strani neuresničljivo željo po spoznanju dokazljivega profila tistega, kar je v njej morda gotovega.

210 Ljudevit Stiasny, Kamnik. Zemljepisno-zgodovinski opis. Ljubljana, 1894, str. 163.

211 Specification $\mathrm{k}$ finančnemu poročilu kamniške župnije za leto 1768, z vodnim znakom Niklove kače na križu iz 50. let 18. stoletja. Gl. op. 67.

212 Gl. op. 14. 


\section{A Contribution Towards the Dating of Manuscripts of Compositions by Jakob Frančišek Zupan \\ Summary}

The study seeks to determine the possible time of the origin of the preserved manuscripts of compositions by Jakob Francišek Zupan by means of the paperological method and to identify the various bandwritings (their number being seven) found in them. In contradistinction to some older interpretations which posit the origin of the composer's early classicistic works into the eighties of the 18th century, our comparative examination of the paper of Zupan's autographs kept in the Franciscan monastery at Novo mesto (arias and duets) has shown that most of it has its origin in the sixties, and some in the fifties and in the seventies and also eighties of the 18 th century. A part of the (identified) paper is of domestic, Slovenian origin, while the remaining part comes from two Carinthian paper mills. Most probably Pitter's two copies of two of Zupan's compositions written in several movements, kept at the chapter house at Novo mesto, could with regard to the age of their paper, of Upper Austrian origin, have originated around the year 1780, and the cathedral copy of bis Te Deum already in the year 1770 . 


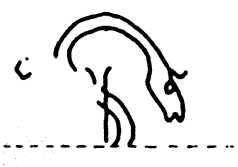

SI. 1
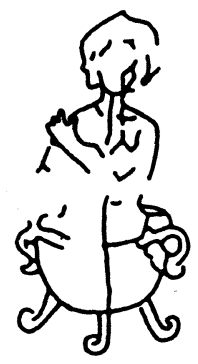

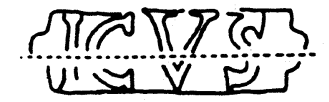

SI. $2 / b$
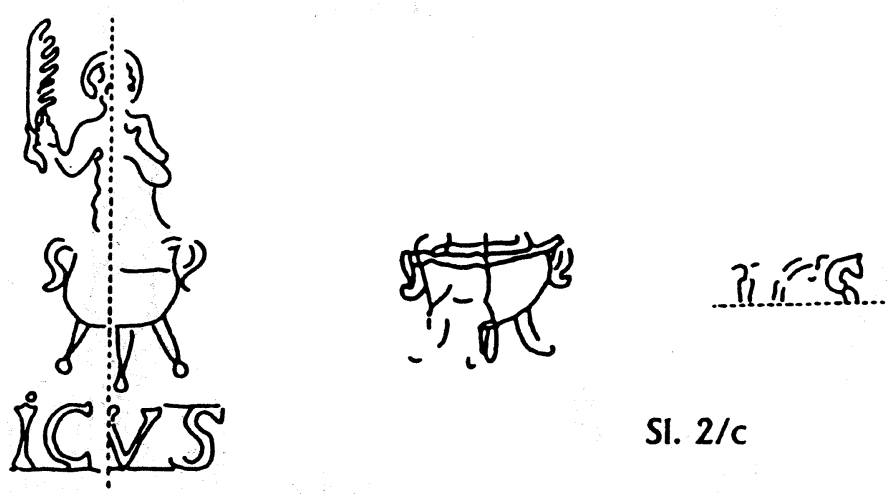

SI. $2 / \mathrm{C}$

SI. $2 / \mathrm{a}$

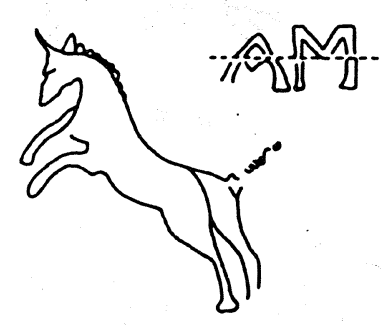

SI. 3/a-1

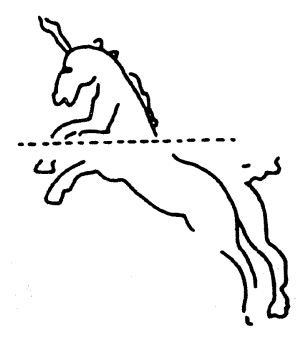

SI. 3/a-2

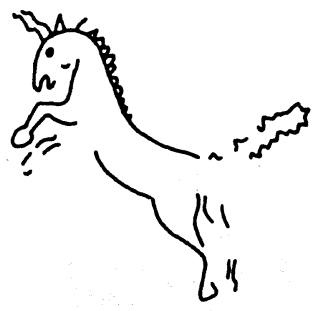

SI. $3 / \mathrm{a}-3$ 
MUZIKOLOŠKI ZBORNIK • MUSICOLOGICAL ANNUAL XXXIV
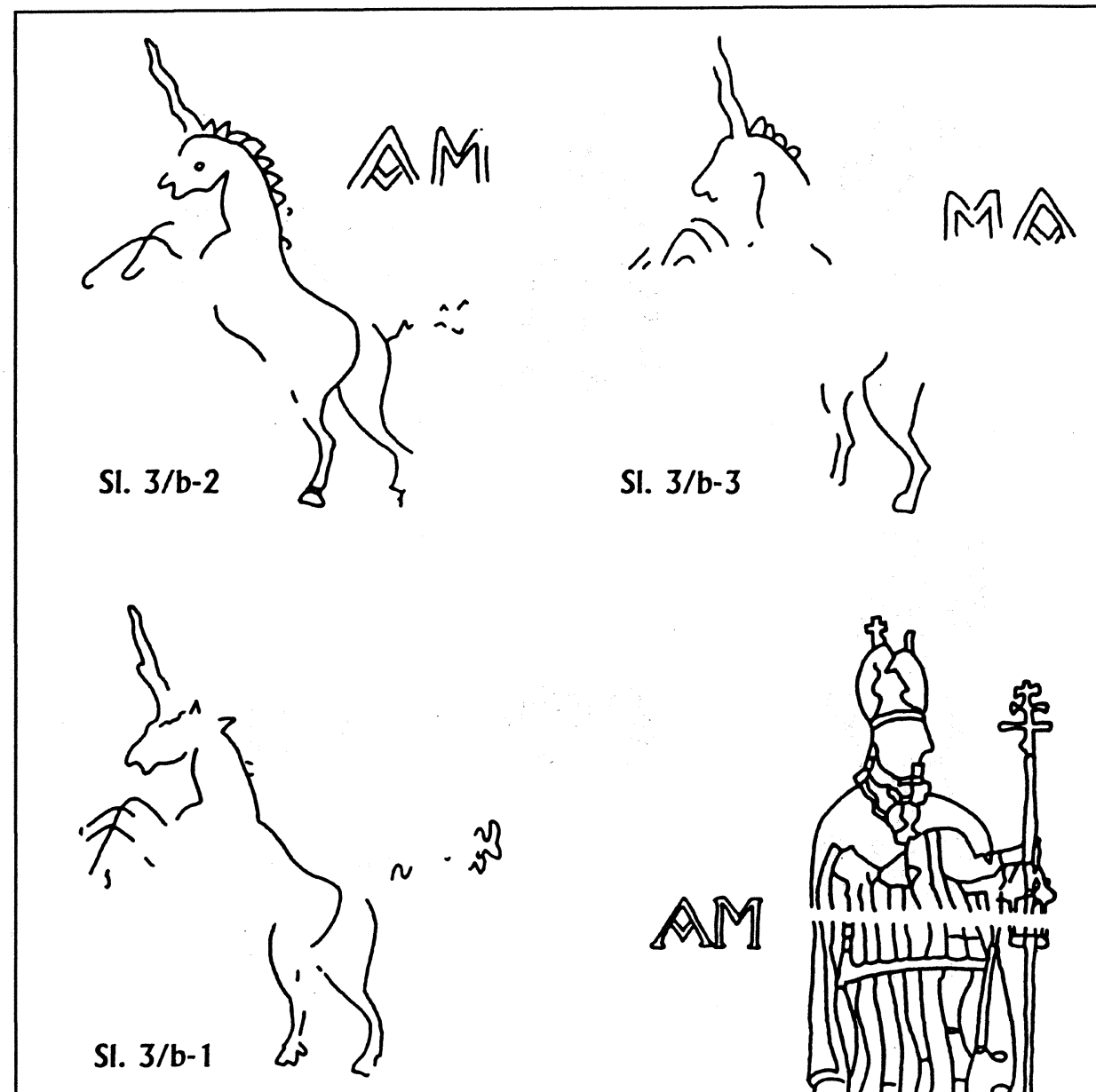

SI. $3 / b-3$
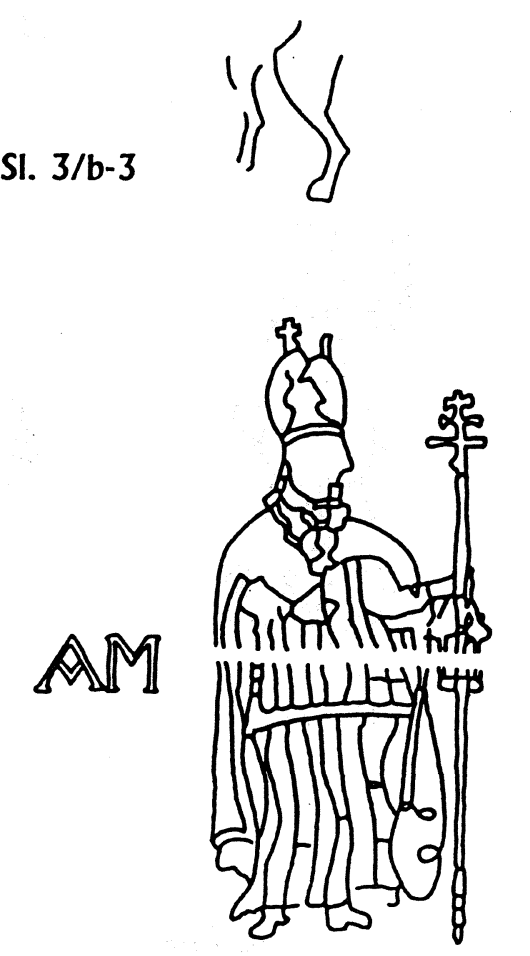

SI. 4
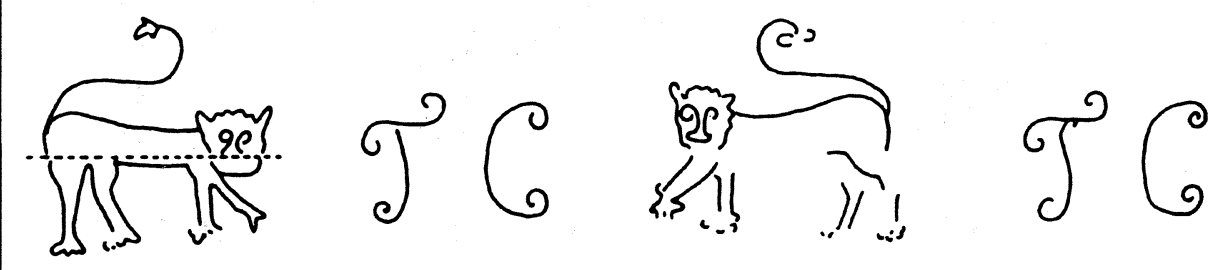

SI. 5/a

SI. $5 / b$

64 


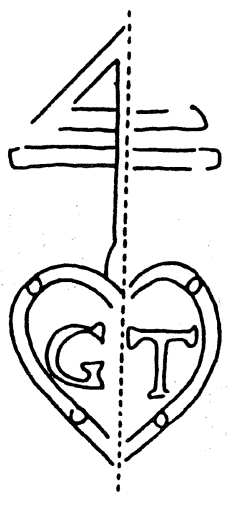

SI. 6

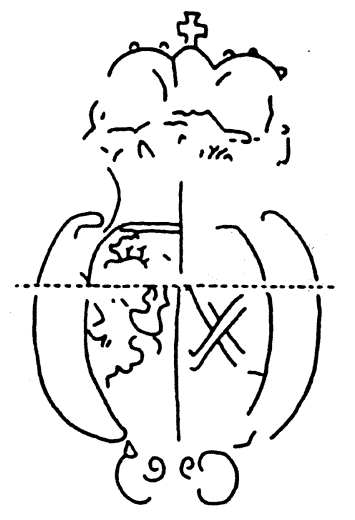

SI. 7

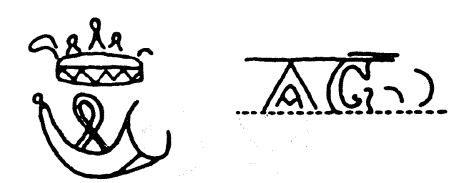

SI. $8 / \mathrm{a}$

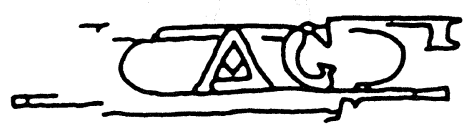

SI. $8 / \mathrm{b}$
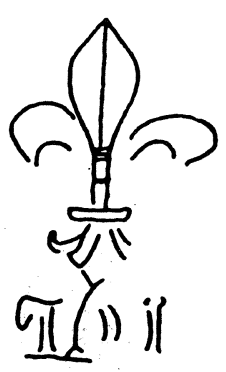

SI. 9

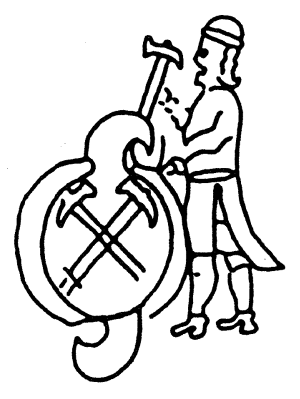

IIE⿱乛龰己

SI. 10 
MUZIKOLOŠKI ZBORNIK • MUSICOLOGICAL ANNUAL XXXIV

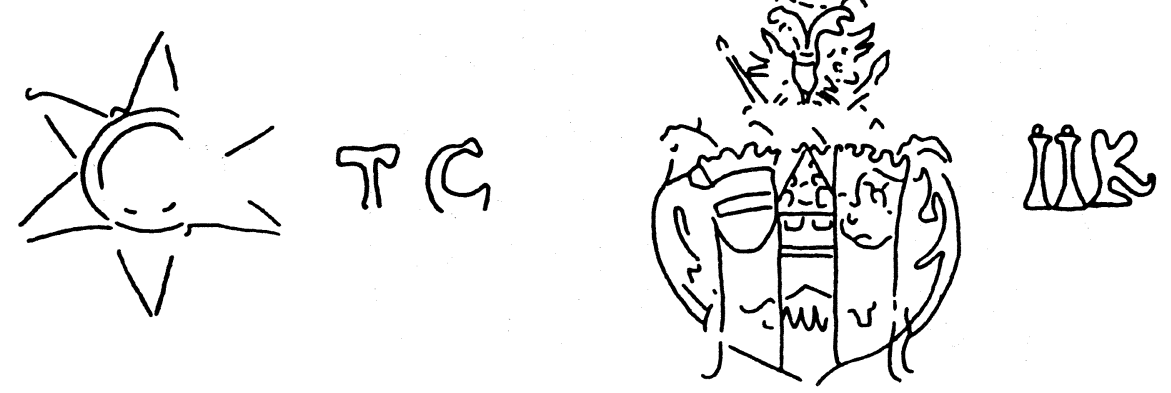

SI. 11

SI. 12
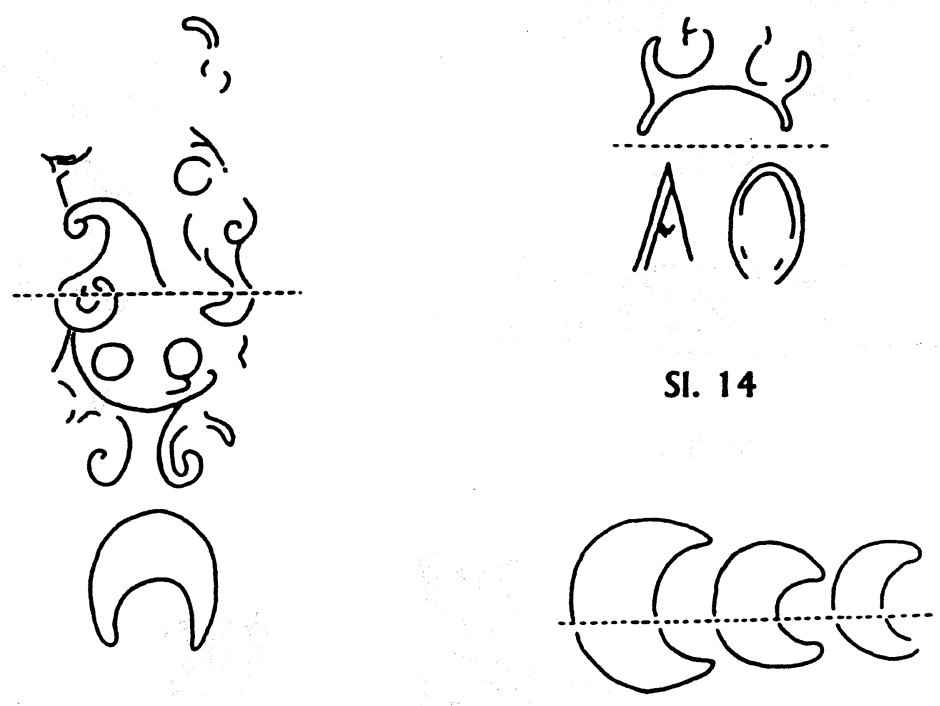

SI. 13

SI. 15

66 
MUZIKOLOŠKI ZBORNIK • MUSICOLOGICAL ANNUAL XXXIV

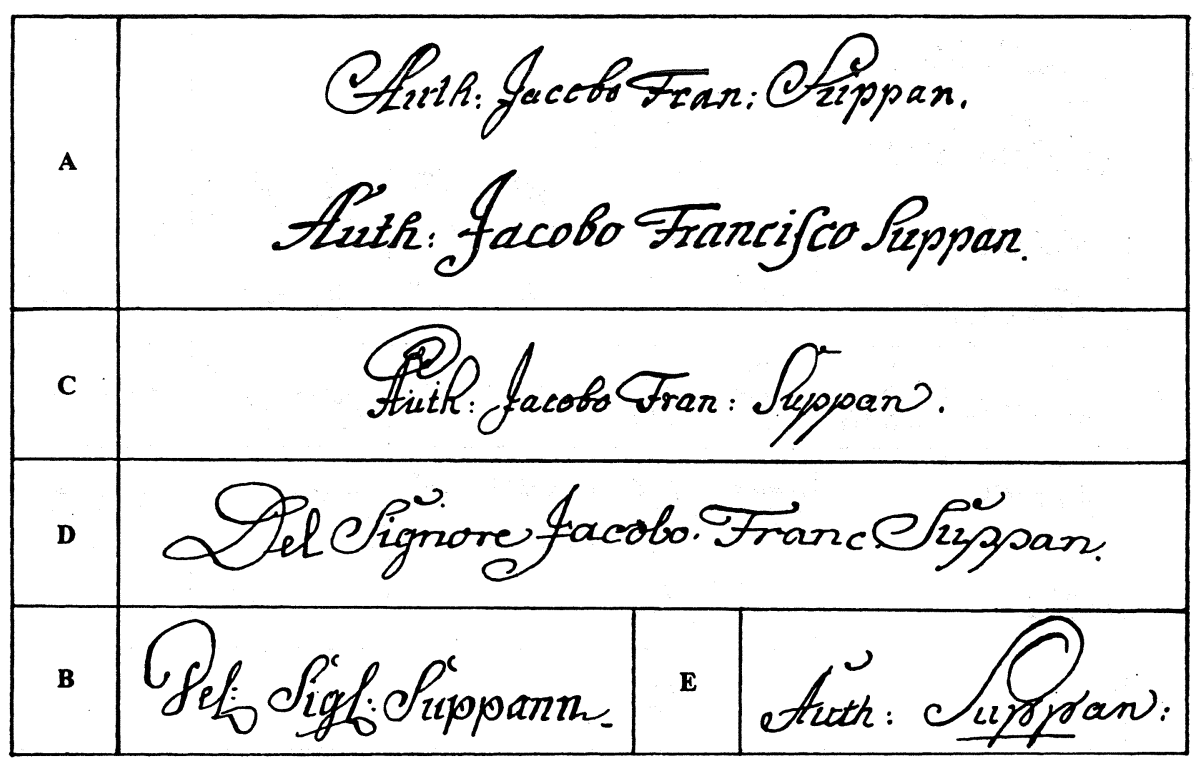

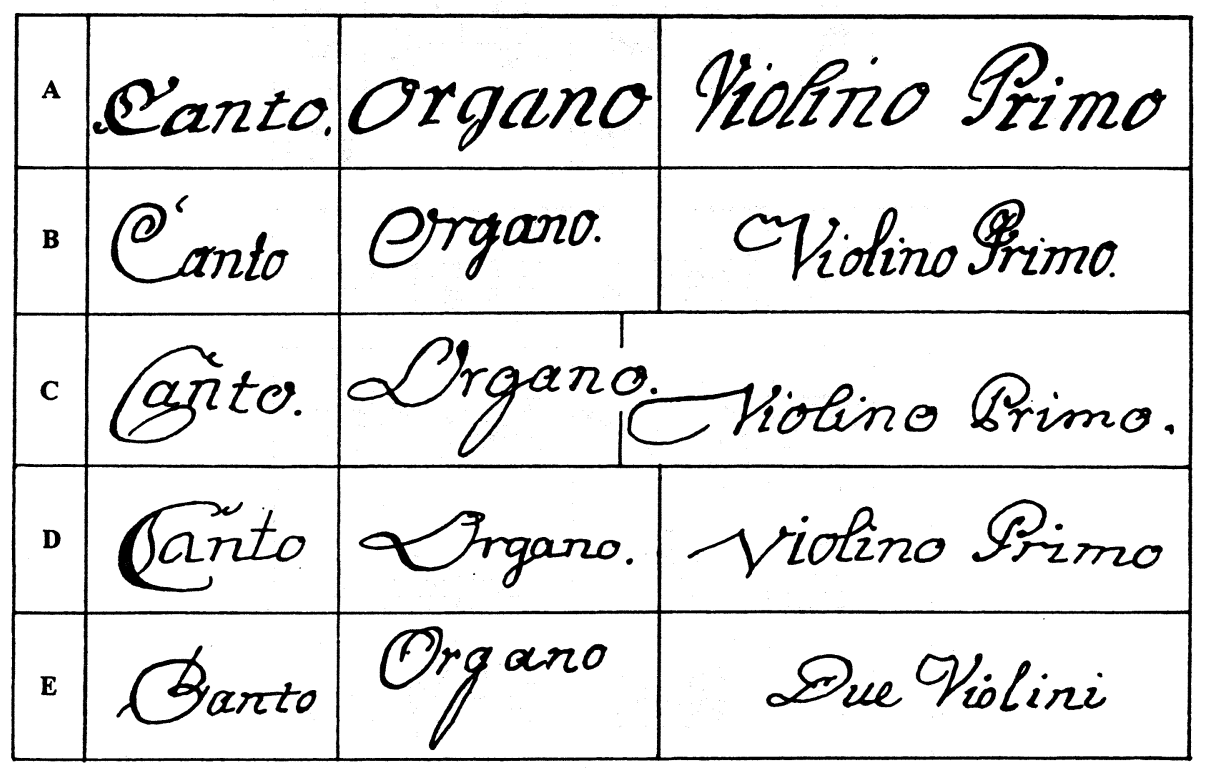

67 
MUZIKOLOŠKI ZBORNIK • MUSICOLOGICAL ANNUAL XXXIV

\begin{tabular}{|c|c|c|c|c|c|c|}
\hline $\mathbf{A}$ & $\begin{array}{l}\text { Amoanc } \\
\text { Afredante } \\
\text { And: } \\
\text { Andante. }\end{array}$ & $\pi$ & $\begin{array}{l}0: \\
0 ?\end{array}$ & $\begin{array}{l}\text { pia: p: } \\
\text { pian p: }\end{array}$ & $\begin{array}{l}\text { for fo f. } \\
\text { gronle }\end{array}$ & $\begin{array}{l}n: n_{0}: n \\
n: 4: n_{0}\end{array}$ \\
\hline B & ofnelente Autte & ๑) & dolo. & pia. p. & for: of & $z t t$ \\
\hline C & Angte & $\Phi_{3}$ & Sol. & pia: pp: & for: & $t . t . t$. \\
\hline D & cfnz: & भ: & $\mathscr{L}$ & $p^{\prime}$ & $\mathcal{A}$ & \\
\hline $\mathbf{E}$ & & & e ollo & & & \\
\hline
\end{tabular}

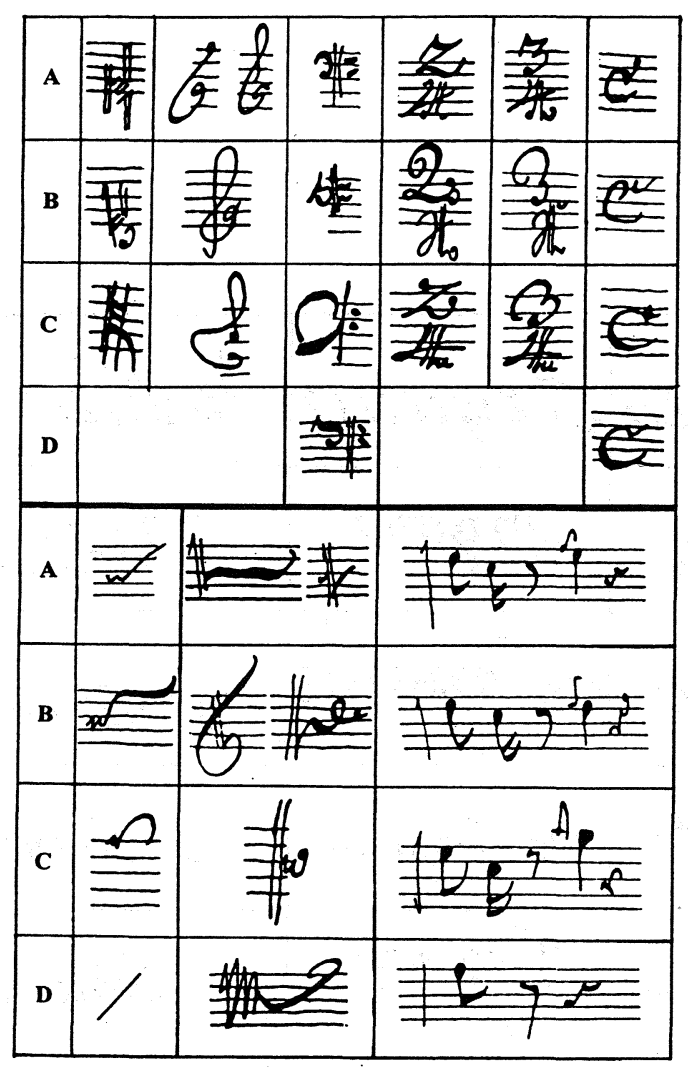

